\title{
Yatırım Amaçlı Gayrimenkullerin Örnek Vakalarla İncelenmesi
}

\author{
Mahmut DEMİRBAŞ **
}

\section{$\ddot{O Z Z E T}$}

Bu çalışmada, TMS 40 'ye göre "yatırım amaçlı gayrimenkuller" kavramı, muhasebeleştirilmesi, amortismanı, sınıflandırılması, gerçeğe uygun değerinin hesaplaması, değerinin artması veya düşmesi, finansal durum tablosu ve kapsaml gelir tablosu dipnotlarında ne şekilde yer alabileceği, nakit giriş ve çıkışlarının bugünkü değerinin nasıl hesaplanacağı, intifa hakkı kavramı ve seçimlik hakların önemi örneklendirilmis vaka ve notlar ile incelenmiştir. Faaliyet kiralaması yoluyla edinilen yatırım amaçlı maddi duran varlıklarla ilgili muhasebe kayıtları kapsamlı olarak ele alınmıştır, bir vakıftan restorasyon veya onarım karşılı̆̆ı uzun süreli faaliyet kiralaması kapsamındaki bir gayrimenkulün yatırım amaçlı gayrimenkul olarak sinıflandırılması ayrıntılı olarak incelenmiştir. Sonuç olarak; ilgili standardın gerektirdiği gibi raporlama yapılabilmesi için hesap planımızın yetersiz kalması gerçeğinden dolayl, hesap planının güncellenmesi önerilmiştir.

Anahtar Kelimeler: Yatırım Amaçlı Gayrimenkuller, Faaliyet Kiralaması, Maddi Duran Varlıklar TMS 40

JEL Sinıflandirması: $M 40$, M41, M48.

\section{To Explain With Exemplified Cases Of Real Estate Propety For Investment Purpose}

\section{ABSTRACT}

In this study, the concept of "real estate property for investment purpose" accordance with Turkish Accounting Standard (TAS) 40, the accounting treatment, depreciation, classification, fair value calculation, increase or decrease in value, financial position table and table of comprehensive income, the present value of cash inflows and outflows the notion of usufruct and the rights of optional rights were examined with examples and notes. The accounting records of investment property acquired through operating leases have been comprehensively handled and the classification of an immovable property for long-term operation lease as restoration or repair as an investment property has been examined in detail. As a result; it has been proposed to update the account plan due to the fact that our account plan is insufficient to enable reporting as required by the relevant standard. TMS 40

Keywords: Real Estate Property For Investment Purpose, Operational Leasing, Fixed Assets, Jel Classification: M40, M41, M48.

** Doç. Dr. Mahmut Demirbaş, Avrasya Üniversitesi, İktisadi ve İdari Bilimler Fakültesi, mahmut.demirbas@avrasya.edu.tr 


\section{GíRiş}

Yatırım amaçlı gayrimenkul, mal veya hizmet üretiminde tedarikinde veya idari amaçla kullanılmak veya normal iş akışı çerçevesinde satılmak gibi amaçlardan ziyade, kira geliri veya sermaye değer artış kazancı ya da her ikisini birden elde etmek amacıyla, sahibinin satın alma, finansal kiralama sözleşmesi çerçevesinde kiracı tarafından elde tutulan arsa veya binalar ile faaliyet kiralaması çerçevesinde kiracı tarafindan elde tutulan gayrimenkullerdir. Bir varlığı yatırım amaçlı gayrimenkul olarak sınıflandırırken o varlığın sürekli gerçeğe uygun değerinin ölçülebilmesinin gereklidir. İhtiyatlılık ve dönemsellik kavramı gereği dönem ayrıştırıcı hesapları kullanırken alacak, borç ve gelirlerini gerçeğe uygun değerleri ile muhasebeleştirilmesi mali tabloların güvenilirliği, sözleşmeye dayanan hak ve yükümlüklerin nazım hesaplarda takip edilmesi de işletmenin sürekliliği hakkında bilgi sahibi olmak ve tam açıklama kuralına uymak açılarından önemlidir. Ayrıca, reel sektörde çok fazla yapılan bir vakıftan restorasyon veya onarım karşıllğı uzun süreli faaliyet kiralaması kapsamındaki bir gayrimenkulün hangi şartlarda yatırım amaçlı olarak sınıflandırılabileceği ve ne şekilde muhasebeleştirilmesi gerektiği makalemizde incelemiştir. Örnek vaka ve notlar ile nakit giriş ve çıkışlarının bugünkü değerinin nasıl hesaplanacağı, intifa hakkı kavramı, yatırım amaçlı gayrimenkullerdeki değer artışlarının muhasebeleştirilmesi ve gerçeğe uygun değerin sürekli ölçülebilmesi ile seçimlik hakların kullanımı incelenmiştir.

\section{YATIRIM AMAÇLI GAYRIMENKULLERINN TANIMI VE MUHASEBELEŞTIRILMESI}

$\mathrm{Bu}$ bölümde, yatırım amaçlı gayrimenkullerin tanımı, muhasebeleştirilmesi, amortismanı, sınıflandırılması, gerçeğe uygun değerinin ölçülebilmesi, değerinin artması veya düşmesi ve finansal durum tablosu ve kapsamlı gelir tablosu dipnotlarında ne şekilde yer alabileceği konularına yer verilmiştir.

\subsection{Yatırım Amaçlı Gayrimenkulün Tanımı}

Yatırım amaçlı gayrimenkul, mal veya hizmet üretiminde tedarikinde veya idari amaçla kullanılmak veya normal iş akışı çerçevesinde satılmak gibi amaçlardan ziyade, kira geliri veya sermaye değer artış kazancı ya da her ikisini birden elde etmek amacıyla, sahibi veya finansal kiralama sözleşmesi çerçevesinde kiracı tarafindan elde tutulan arsa veya binalar ile faaliyet kiralaması çerçevesinde kiracı tarafindan elde tutulan gayrimenkullerdir (TMS 40, m:5). Yatırım amaçlı gayrimenkullerin işletmenin elinde bulunan diğer varlıklardan bağımsız olarak nakit sağlaması önemli bir noktadır (Netek, 2012: 1). Bağımsız nakit akışı ve sermaye kazancı sağlaması yatırım amaçlı gayrimenkullerin, diğer gayrimenkullerden ayırt edilmesini sağlamaktadır (Güngör,2011:18).

\subsection{Yatırım Amaçlı Gayrimenkulün Muhasebeleştirilmesi}

Yatırım amaçlı gayrimenkulün ilk ediniminde maliyet bedeli üzerinden muhasebeleştirilmesi gerektirir. Maliyeti; satın alma fiyatı ile satın alma işlemi ile ilişkili avukatlık ücreti, komisyon ücreti, gayrimenkul alım vergisi ve diğer işlem maliyetleri gibi maliyet unsurlarından oluşur. İşletmenin kendisi tarafindan inşa edilen yatırım amaçlı gayrimenkulün maliyetinin belirlenmesinde inşa maliyeti unsurlarından oluşur(Küçük, 2012: 80). 
Değerleme işleminin önemi, değerlemeden beklenen fonksiyonların yerine getirilmesi ile doğrudan ilişkilidir. Çünkü değerleme fonksiyonları, işletmenin sürekliliğini sağlayan en önemli unsurlardan biridir. Değerleme fonksiyonlarından beklenen faydanın sağlanabilmesi, seçilen değerleme ölçülerinin doğruluğu kadar, dönemler arası tutarlılığına da bağlıdır (Fatih Üner, 2015:36, Tokay ve Deran, 2008: 22).

Yatırım amaçlı gayrimenkulün gerçeğe uygun değerinin* elde edilecek faydanın üzerinde bir maliyete katlanmaksızın güvenilir olarak sürekli şekilde belirlenebildiği durumlarda, gerçeğe uygun değer yöntemi kullanılmalıdır. Gerçeğe uygun değerinin elde edilecek faydanın üzerinde bir maliyete katlanılacaksa ise veya gerçeğe uygun değerinin belirlenmesi imkansız yakın ise maliyet yöntemi ile muhasebeleştirilmesi yapılmalıdır (TMS 40 m:21). Maliyet modeli ile ölçülen yatırım amaçlı gayrimenkulün gerçek değeri dipnotlarda gösterilmek zorundadır. Ancak bu zorunluluk sahibi tarafindan kullanılan gayrimenkullerde ve stoklarda bulunmamaktadır (Ufuk, 2008:.1). Maliyet yöntemini kullanan yatırım amaçlı gayrimenkulün zamanla gerçeğe uygun değerinin ölçülmesinin imkan dahilinde olması durumunda imkanın doğduğu zaman dilimini içeren dönemi de kapsayacak şekilde yatırım amaçlı gayrimenkul gerçeğe uygun değeri üzerinden gösterilecektir (Deloitte Academy, Kapsamlı UFRS Eğitim :5).

Gerçeğe uygun değerde meydana gelen değişiklikler her bir raporlama tarihinde gelir tablosu ile ilişkilendirilir. Yatırım amaçlı gayrimenkul maliyet bedeli üzerinden ölçüldügüunde temel sorunlar varlığın başlangıç maliyetinin, beklenen yararlı ömrünün ve amortisman döneminin belirlenmesi ile söz konusu varlığa ilişkin olarak herhangi bir değer düşüklüğü zararının muhasebeleştirilip muhasebeleştirilmeyeceği konusunun değerlendirilmesidir. Böyle bir yatırım amaçlı gayrimenkul kalemi, beklenen ekonomik ömrü boyunca itfa edilir (Deloitte Academy:1-8).

\subsection{Yatırım Amaçlı Gayrimenkulün Amortismanı}

Yatırım amaçlı bir gayrimenkulün gerçeğe uygun değerinin belirlenemediği durumlarda, kalıntı değeri de belirlenemez. İşletmeler bu hususta zorunlu tutulmaz. Kalıntı değerinin sıfır olarak kabul edilmesini gerektirmektedir (TMS 40, m: 53).

Amortisman yöntemi ve oranı yıllık olarak gözden geçirilir. Ayrıca, her bir raporlama tarihinde maddi duran varlık olarak muhasebeleştirilen herhangi bir yatırım amaçlı gayrimenkul kaleminde değer düşüklügü olabileceği yönünde herhangi bir göstergenin bulunup bulunmadığ (yani defter değerinin geri kazanılabilir tutarını aşıp aşmadığı) değerlendirilir. Bu tür bir göstergenin bulunması durumunda, söz konusu yatırım amaçlı gayrimenkul kalemi değer düşüklüğü açısından test edilir (yani gayrimenkulün geri kazanılabilir tutarı belirlenir ve varsa değer düşüklüğü zararı muhasebeleştirilir).

Yatırım amaçlı bir gayrimenkulün sınıflandırılmasında uygulanan aşırı maliyet ve çaba kuralı, değer düşüklüğüne uğramış olabileceği yönünde göstergelerin bulunduğu bir yatırım amaçlı gayrimenkulün gerçeğe uygun değerinin hesaplanmasında işletmeye bir

\footnotetext{
* Gerçeğe uygun değer; Karşılıklı pazarlık ortamında, bilgili ve istekli gruplar arasında bir varlığın el değiştirmesi ya da bir borcun ödenmesi durumunda ortaya çıkması gereken tutardır (TMS 40, m:5). Yatırım amaçlı gayrimenkulün gerçeğe uygun değerinin hesaplanmasında, gayrimenkulün tamamlayıcı parçaları bilançoda maddi duran varlık olarak ayrı bir şekilde gösterilmek yerine yatırım amaçlı gayrimenkulün gerçeğe uygun değerine dahil edilirler (TMS 40, m:50).
} 
muafiyet getirmez. Değer düşüklüğü testi açısından geçerli olan aşırı maliyet ve çaba kuralının sınırı, sınıflandırma açısından geçerli olandan daha geniştir.

Yatırım amaçlı bir gayrimenkul kalemi elden çıkarıldığında, söz konusu işleme ilişkin kazanç ya da kayıp, gelir tablosu ile ilişkilendirilir.

\subsection{Yatırım Amaçlı Gayrimenkulün Sınıflandırılmasında Değişim}

Yatırım amaçlı bir gayrimenkulün dahil olduğu sınıflandırılmadan başka bir sınıflandırma kapsamına alınması veya yatırım amaçlı gayrimenkul olarak önce sinıflandırılmayan bir duran varlığı yatırım amaçlı gayrimenkul olarak sınıflandırılması; sadece kullanımında bir değişiklik olduğu zaman yapılır. Kullanım değişiklikleri; "yatırım amaçlı gayrimenkulün sonradan sahibi tarafindan kullanıma başlanması (maddi veya maddi olmayan duran varlık olarak muhasebeleştirilir), yatırım amaçlı gayrimenkulden stoklara transfer için satış amacıyla geliştirilmeye başlanması (satış amaçlı gayrimenkuller olarak muhasebeleştirilir)(TMS 40, m.9), sahibi tarafindan kullanılan bir gayrimenkulün yatırım amaçlı duruma gelmesi (maddi veya maddi olmayan duran varlıklardan çıkartılıp, yatırım amaçlı gayrimenkullere dahil edilir), inşa ve geliştirme sonrası yatırım amaçlı gayrimenkul durumuna gelmesi (yapılmakta olan yatırımlardan çıkartılıp, yatırım amaçlı gayrimenkullere dahil edilmesi), daha önce satış amaçlı gayrimenkul iken faaliyet kiralaması suretiyle kiralamanın başlaması (satış amaçlı gayrimenkullerden çıkarılıp, yatırım amaçlı gayrimenkul rubuna dahil edilmesi)" ş̧eklinde karşımıza çıkabilir. Sınıflandırma değişimlerinde gayrimenkulün defter değerini değiştirilmez (TMS 40 m:59).

Bir işletme, gerçeğe uygun değer esasından izlenecek olan kendisi tarafindan inşa edilen veya geliştirilen yatırım amaçlı gayrimenkulün inşa veya geliştirilmesi işlemini tamamladığında; gayrimenkulün, tamamlanma tarihindeki gerçeğe uygun değeri ile daha önce gösterildiği defter değeri arasındaki farkı kâr veya zarar olarak muhasebeleştirir (TMS 40,m.65).

Yatırım amaçlı gayrimenkulün kullanım dışı kalması veya elden çıkarılması durumunda meydana gelen kazanç veya kayıplar; varlığın elden çıkarılmasından kaynaklanan net hasılat ile gayrimenkulün defter değeri arasındaki farktır ve kullanıma son verilme veya elden çıkarılma döneminde gelir tablosunda muhasebeleştirilir (TMS 40 m:69).

TFRS 15'e göre, bir sözleşmenin taraflarınca kararlaştırılan ödemelerin zamanlaması (açıkça ya da zımnen), müşteriye veya işletmeye, mal veya hizmetlerin müşteriye devrinin finansmanı şeklinde önemli bir fayda sağliyorsa, işletme işlem bedelini belirlerken taahhüt edilen bedelde paranın zaman değerinin etkisine göre düzeltme yapar. Bu koşullarda sözleşme önemli bir finansman bileşeni içermektedir. Önemli bir finansman bileşeninin mevcudiyeti için, finansman taahhüdünün sözleşmede açıkça belirtilmiş olması veya sözleşmenin taraflarınca mutabık kalınan ödeme şartlarından zımnen anlaşılıyor olması fark etmez (TFRS 15,m.60). Müşteriye taahhüt ettiği mal veya hizmetin devir tarihi ile müşterinin bu mal veya hizmetin bedelini ödediği tarih arasında geçen sürenin bir yıl veya daha az olacağını öngörmesi durumunda, taahhüt edilen bedelde önemli bir finansman bileşeninin etkisi için düzeltme yapmak zorunda değildir (TFRS 15,m.63). İşletme, taahhüt edilen bedeli önemli bir finansman bileşeni kadar düzeltirken, sözleşme başlangıcında işletme ile müşterisi arasında ayrı bir finansman işlemi yapılmış olsaydı, bu işleme yansıtılacak iskonto oranını kullanır. $\mathrm{Bu}$ 
oran, sözleşmeye göre finansmanı alan tarafın kredi özelliklerinin yanı sıra, sözleşme kapsamında devredilen varlıklar dâhil müşteri veya işletme tarafından sağlanan teminat veya güvenceleri yansıtabilir. İşletme bu oranı, taahhüt edilen bedelin nominal tutarını, mal ve hizmetler müşteriye devredildiği anda (veya devredildikçe) müşteri nakden ödeme yapmış olsaydı bu durumda ödeyeceği fiyata indirgeyen oranı belirlemek suretiyle saptayabilir. Sözleşme başladıktan sonra, faiz oranları veya diğer şartlarda meydana gelen değişiklikler için (müşterinin kredi riskine ilişkin değerlendirmede bir değişiklik gibi) iskonto oranında güncelleme yapılmaz (TFRS 15,m 64). İşletme, finansmanın etkilerini (faiz gelirleri veya giderlerini) müşterileriyle yaptığı sözleşmelerden doğan hasılattan ayrı olarak kapsamlı gelir tablosunda sunar. Faiz gelirleri ve faiz giderleri, müşteri ile yapılan sözleşmenin bir sözleşme varlığ1 (veya alacağı) veya bir sözleşme yükümlülüğü olarak muhasebeleştirilmesi ölçüsünde finansal tablolara alınır (TFRS 15,m.65).

Yatırım amaçlı bir gayrimenkulün elden çıkarılması karşılığında alınacak tutarlar başlangıçta gerçeğe uygun değer esasına göre muhasebeleştirilir. Özellikle yatırım amaçlı gayrimenkul için yapılacak ödemelerin ertelenmiş olması durumunda, alınacak söz konusu tutarlar, ilk başta peşin fiyat eşdeğerlerinden muhasebeleştirilir. Alacak tutarının nominal

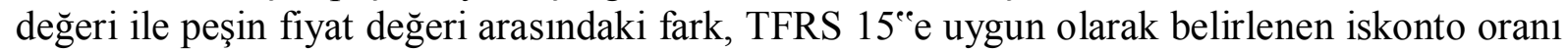
ve iç iskonto yöntemini kullanılarak hesaplanır. Varlıktan gelecekte elde edilecek gelir ile bu gelirlerinin net bugünkü değeri arasındaki fark, faiz geliri olarak muhasebeleştirilir (TFRS $15, \mathrm{~m} .65)$.

Varlığın geçiş tarihindeki değeri ile kayıtlı değeri arasındaki farkın muhasebeleştirilmesi, varlığın değerinde azalış veya artış olmasına göre farklılık arz eder. Azalış olması durumunda azalış tutarı, eğer varlığa ilişkin bir değer artış fonu yoksa doğrudan dönem kar veya zararına dâhil edilir. Eğer değer artış fonu varsa, azalış tutarı öncelikle buradan indirilmelidir (TMS 40, m: 62). Artış olması durumunda artış tutarı, eğer önceki dönemlerde varlık için kayda alınmış değer azalışı varsa, bu azalış telafi edilene kadar gelir tablosu ile ilişkilendirilmez. Gelir tablosu ile ilişkilendirilen tutar, varlığın kayıtlı değerine getirilmesi için gerekli olan tutarı aşamaz. Buradaki kayıtlı değer, varlığın kayıtlı değerinden birikmiş amortismanlar düşüldükten sonraki değeri ifade etmektedir. Bu hesaplamada değer düşüklükleri dikkate alınmaz. Gelir tablosu ile ilişkilendirilmesi gereken tutardan sonra halen kalan bir tutar varsa, bu tutar yeniden değerleme değer artışı olarak özkaynaklara eklenebilir. Varlığın elden çıkarılması durumunda, yeniden değerleme değer artışı olağanüstü yedeklere (dağıtılmamış karlara) eklenebilir. Bu tutar dönem kar ve zararına dahil edilmez (Örten vd. 2012: 627).

\subsection{Yatırım Amaçlı Gayrimenkulün Değerinin Artması veya Düşmesi}

Yatırım amaçlı gayrimenkulün değerinin düşmesi, kayıp olması veya terk edilmesi nedeniyle üçüncü şahıslardan alınacak tazminat tahsil edilebilir olduğu zaman gelir tablosu ile ilişkilendirilir (TMS 40, m: 72). Yatırım amaçlı gayrimenkuldeki değer düşüklükleri veya zararlar, bunlara ilişkin olarak üçüncü şahıslardan tazminat talepleri veya üçüncü şahıslardan alınan tazminatlar ile bunların yerine konulan varlıkların sonraki inşa veya satın alınma işlemleri ayrı iktisadi olaylardır ve aşağıda belirtilen şekillerde ayrı ayrı muhasebeleştirilirler (TMS 40, m:. 73) 
a) Yatırım amaçlı gayrimenkuldeki değer düşüklükleri TMS 36'ya göre muhasebeleştirilir.

b) Yatırım amaçlı gayrimenkulün kullanımına son verilmesi veya elden çıkarılması standartta bahsedilen şekliyle muhasebeleştirilir (elden çıkarıldığı veya kullanımına sürekli bir şekilde son verildiği ve kendisinden gelecekte herhangi bir ekonomik fayda beklenmediği durumlarda finansal durum tablosu (bilanço) dışı bırakılır (finansal durum tablosundan (bilançodan) çıkartılır).

c) Değer düşüklüğüne uğrayan, kaybolan veya terk edilen yatırım amaçlı gayrimenkullere ilişkin olarak üçüncü şahıslardan alınacak tazminatlar, tahsil edilebilir oldukları zaman gelir tablosu ile ilişkilendirilir.

d) Yerine konulan varlığın restore edilmesi, satın alınması veya inşasına ilişkin maliyeti bu TMS 40 nolu standartta usul ve esaslar çerçevesinde tespit edilir (Üner, 2015:51).

\subsection{Yatırım Amaçlı Gayrimenkuller İle İlgili Dipnotlar}

Yatırım amaçlı gayrimenkuller için bilanço ve gelir tablosu dipnotlarında verilmesi gereken bilgiler aşağıdaki gibidir (TMS 40, m: 75). Gerçeğe uygun değer yöntemini mi yoksa maliyet yöntemini mi uyguladığı, gerçeğe uygun değer yöntemini uygulaması durumunda; faaliyet kiralaması aracılığıyla elinde bulundurduğu gayrimenkul haklarının yatırım amaçlı gayrimenkul olarak sinıflandırılıp sınıflandırılmadığı ile bu şekilde muhasebeleştirilip muhasebeleştirilmediği ve bunların hangi koşullar altında yapılmış olduğunu, Sınıflandırma işleminin zor olduğu durumlarda (bakınız: Paragraf 14), olağan iş akışı içinde, yatırım amaçlı gayrimenkulün sahibi tarafindan kullanılan gayrimenkulden ve satış için elde tutulan gayrimenkulden hangi kriterler çerçevesinde ayırt edildiğini, faaliyet kiralaması aracılığıyla elinde bulundurduğu gayrimenkul haklarının yatırım amaçlı gayrimenkul olarak sınıflandırılıp sınıflandırılmadığ ile bu şekilde muhasebeleştirilip muhasebeleştirilmediği ve bunların hangi koşullar altında yapılmış olduğunu, yatırım amaçlı gayrimenkulden elde edilen kira gelirleri, Dönem içinde kira geliri elde edilmiş yatırım amaçlı gayrimenkulün doğrudan faaliyet giderleri (bakım ve onarım giderleri dahil) ve dönem içinde herhangi bir kira geliri sağlamamış yatırım amaçlı gayrimenkulün doğrudan faaliyet giderleri (bakım onarım giderleri dahil), maliyet yöntemi ile ölçülen bir varlık grubundan, gerçeğe uygun değer yöntemi kullanılan diğer bir gruba satışı yapılan yatırım amaçlı gayrimenkulün gerçeğe uygun değerinde meydana gelen ve kâr veya zarar hesabında muhasebeleştirilen değişiklik toplamı hakkında bilgiler, Yatırım amaçlı gayrimenkulün nakde çevrilebilme veya gelirlerinin ve elden çıkarılma durumunda elde edilecek tutarın tahsil edilebilme durumuna ilişkin kısıtlamalar ve bunların tutarları, Yatırım amaçlı gayrimenkule ilişkin satın alma, inşa veya geliştirme ya da bakım ve onarım veya iyileştirme konularındaki sözleşmeye bağlı yükümlülükler yer almaktadır. Eğer bir yatırım amaçlı gayrimenkulden faaliyet kiralaması yoluyla gelir elde edilmesi veya faaliyet kiralaması yoluyla bir yatırım amaçlı gayrimenkul edinilmesi söz konusu ise "TFRS 16 Kiralamalar" standardı doğrultusunda yapılması gereken açıklamalarda yer vermesi gerekmektedir. 


\section{3. ÖRNEK VAKALARLA YATIRIM AMAÇLI GAYRİMENKULLER}

Çalışmamızın üçüncü bölümünde örnek vakalara yer verilmiştir. Vakalar ile incelenen yatırım amaçlı gayrimenkullerde ihtiyatlılık ve dönemsellik kavramı gereği dönem ayrıştırıcı hesapları kullanılmıştır. İlgili gelirler ve giderler yevmiye kayıt tarihi itibariyle gerçeğe uygun değerleri ile kayda alınmıştır. TFRS 16 faaliyet kiralaması yoluyla elde edilen yatırım amaçlı gayrimenkuller ve bu gayrimenkullerin edinimi sürecinde katlanılan maliyetler ile elde edilecek faaliyet kiralamasından gelirler için nakit giriş ve çıkışlarının bugünkü değeri hesaplanmış, muhasebe kayıtları ile intifa hakkı kavramına yer verilmiştir.

ÖRNEK VAKA 1; Ortaköy işletmesi daha önce kendisinin kullandığı ve aktifinde binalar hesabın 800.000 TL (Arsa bedeli 420.000 TL, Yap1 Bedeli 380.000 TL, Birikmiş Amortismanı 35.400 TL ) bedelle bulunan Çengelköy'deki 2 katlı müstakil bir yapıyı 1 Haziran 2016 tarihinde aylık 5.000 TL + KDV bedelle 3 yıllığına Bebek işletmesine faaliyet kiralaması sözleşmesi ile kiralamıştır. Yıllık Kira artışı \%8'dir. Kiralama aşamasında 20.000 TL depozito ve bir aylık kira bedelini aynı gün $Z$ bankasına yapılan havale ile tahsil etmiştir. Bebek firması yönetim departmanı tarafından kullanılmak üzere, kiralama sözleşmesi dayanarak kiraladığı müstakil yapıyı etkin kullanabilmek amacıyla, boya, badana ve havalandırma sistemi ile çatı tadilatı yaptırmış 35.000 TL + KDV tutarındaki toplam maliyet bedelini içeren 1 Temmuz 2016 tarihli faturayı aynı gün V bankasından aracılığıyla ödemiştir. Ortaköy işletmesi için ilgili yapının ekonomik ömrü 50 yıldır ve normal amortisman hesaplama yöntemini kullanmaktadır. Bebek firması özel maliyet kapsamında varlıklarını 5 yılda normal amortisman yöntemine göre amortismana tutarını hesaplamaktadır. KDV Oranı $\% 18$ 'dir.

\begin{tabular}{|c|c|c|c|c|c|c|}
\hline \multicolumn{7}{|c|}{ Ortak İşletmesinin Muhasebe Kaydı } \\
\hline 1 & \multicolumn{3}{|c|}{-------------------------------------01.06.2016-------------------------- } & & BORÇ & \multirow[t]{2}{*}{ ALACAK } \\
\hline 202 & \multicolumn{3}{|c|}{ YATIRIM AMAÇLI GAYRIMENKULLER HESABI } & & 800.000 & \\
\hline 202.02. & \multicolumn{3}{|c|}{ Bebek..Ada... Parsel } & & & \\
\hline 202.02.001 & \multicolumn{3}{|l|}{ Arsa Bedeli } & 420.000 & & \\
\hline 202.02 .002 & \multicolumn{3}{|c|}{ Yapı Bedeli } & 380.000 & & \\
\hline 257 & \multicolumn{3}{|c|}{ BİRIKMIŞ AMORTİSMAN HESABI } & & 35.400 & \\
\hline 257.02. & \multicolumn{3}{|c|}{ Binalar } & & & \\
\hline \multirow[t]{9}{*}{257.02 .002} & \multirow[t]{9}{*}{ Bebek..Aada..Parsel } & & & 35.400 & & \\
\hline & & 252 & BINALAR HESABI & & & \multirow[t]{5}{*}{800.000} \\
\hline & & 252.02. & Bebek.. Ada... Parsel & & & \\
\hline & & 252.02 .001 & Arsa Bedeli & 420.000 & & \\
\hline & & 252.02 .002 & Yapı Bedeli & 380.000 & & \\
\hline & & & BİRİKMİŞ AMORTİSMAN & & & \\
\hline & & 207 & HESABI & & & \multirow[t]{3}{*}{35.400} \\
\hline & & 207.02 & Yatırım Amaçlı Gayrimenkuller & & & \\
\hline & & 207.02 .002 & Bebek..Aada..Parsel & 35.400 & & \\
\hline
\end{tabular}

Not; Ortaköy ve Bebek işletmeleri dönemsellik kavramı gereği dönem ayrıştırıcı hesapları kullanırken alacak, borç ve gelirlerini yevmiye kayıt tarihi itibariyle gerçeğe uygun değerlerini dikkate alarak yevmiye kayıtlarını yapmaktadır. Her iki firmada iskonto sürecinde zımni faiz oranı olarak yıllık nominal \% 12, aylı nominal \% 1 oranlarını muhasebe varsayımı olarak kabul etmiştir. 


\begin{tabular}{|c|c|c|c|c|c|c|c|c|}
\hline & \multicolumn{3}{|c|}{2016 Yilı } & \multicolumn{5}{|c|}{2018 Yilı } \\
\hline Aylar & $\begin{array}{c}\text { Nominal } \\
\text { Kira Tutarı }\end{array}$ & $\begin{array}{l}\text { İskonto } \\
\text { Oranı }\end{array}$ & $\begin{array}{l}\text { İskonto Edilmiş } \\
\text { Kira Tutarı }\end{array}$ & $\begin{array}{c}\text { İskonto } \\
\text { Tutar1 }\end{array}$ & $\begin{array}{c}\text { Nominal } \\
\text { Kira Tutarı }\end{array}$ & $\begin{array}{c}\text { İskonto } \\
\text { Oranı }\end{array}$ & $\begin{array}{c}\text { İskonto Edilmiş } \\
\text { Kira Tutarı }\end{array}$ & $\begin{array}{c}\text { İskonto } \\
\text { Tutarı }\end{array}$ \\
\hline 1 & & & & & 5400 & 1,208 & 4469,8 & 930,2 \\
\hline 2 & & & & & 5400 & 1,220 & 4425,5 & 974,5 \\
\hline 3 & & & & & 5400 & 1,232 & 4381,7 & 1018,3 \\
\hline 4 & & & & & 5400 & 1,245 & 4338,3 & 1061,7 \\
\hline 5 & & & & & 5400 & 1,257 & 4295,4 & 1104,6 \\
\hline 6 & 5000 & $1,000^{\circ}$ & 5000 & 0 & 5832 & 1,270 & 4593,1 & 1238,9 \\
\hline 7 & 5000 & 1,010 & 4950,5 & 49,505 & 5832 & 1,282 & 4547,6 & 1284,4 \\
\hline 8 & 5000 & 1,020 & 4901,5 & 98,5198 & 5832 & 1,295 & 4502,6 & 1329,4 \\
\hline 9 & 5000 & 1,030 & 4853,0 & 147,049 & 5832 & 1,308 & 4458,0 & 1374,0 \\
\hline 10 & 5000 & 1,041 & 4804,9 & 195,098 & 5832 & 1,321 & 4413,9 & 1418,1 \\
\hline 11 & 5000 & 1,051 & 4757,3 & 242,672 & 5832 & 1,335 & 4370,2 & 1461,8 \\
\hline 12 & 5000 & 1,062 & 4710,2 & 289,774 & 5832 & 1,348 & 4326,9 & 1505,1 \\
\hline \multirow[t]{2}{*}{ Toplam } & 35000,0 & & 33977,4 & 1022,6 & 67824,0 & & 53123,0 & 14701,0 \\
\hline & \multicolumn{4}{|c|}{2017 Y $_{1}$} & \multicolumn{4}{|c|}{2019 Yilı } \\
\hline 1 & 5000 & 1,072 & 4663,6 & 336,4 & 5832 & 1,361 & 4284,1 & 1547,9 \\
\hline 2 & 5000 & 1,083 & 4617,4 & 382,6 & 5832 & 1,375 & 4241,6 & 1590,4 \\
\hline 3 & 5000 & 1,094 & 4571,7 & 428,3 & 5832 & 1,389 & 4199,6 & 1632,4 \\
\hline 4 & 5000 & 1,105 & 4526,4 & 473,6 & 5832 & 1,403 & 4158,1 & 1673,9 \\
\hline 5 & 5000 & 1,116 & 4481,6 & 518,4 & 5832 & 1,417 & 4116,9 & 1715,1 \\
\hline 6 & 5400 & 1,127 & 4792,2 & 607,8 & & & & \\
\hline 7 & 5400 & 1,138 & 4744,8 & 655,2 & & & & \\
\hline 8 & 5400 & 1,149 & 4697,8 & 702,2 & & & & \\
\hline 9 & 5400 & 1,161 & 4651,3 & 748,7 & & & & \\
\hline 10 & 5400 & 1,173 & 4605,2 & 794,8 & & & & \\
\hline 11 & 5400 & 1,184 & 4559,6 & 840,4 & & & & \\
\hline 12 & 5400 & 1,196 & 4514,5 & 885,5 & & & & \\
\hline Toplam & 62800,0 & & 55426,2 & 7373,8 & 29160,0 & & 21000,3 & 8159,7 \\
\hline
\end{tabular}

\begin{tabular}{|l|c|c|c|}
\hline Y1llar & Nominal Kira Tutar1 & $\begin{array}{c}\text { İskonto Edilmiş Kira } \\
\text { Tutar1 }\end{array}$ & İskonto Tutar1 \\
\hline 2016 Y1l1 & 35.000 & $33.977,40$ & 1022,6 \\
\hline 2017 Y11 & 62.800 & $55.426,20$ & 7373,8 \\
\hline 2018 Y11 & 67824 & 53123 & 14701 \\
\hline 2019 Y1l1 & 29160 & 21000,3 & 8159,7 \\
\hline Toplam & $\mathbf{1 9 4 . 7 8 4}$ & $\mathbf{1 6 3 . 5 2 7}$ & $\mathbf{3 1 . 2 5 7}$ \\
\hline
\end{tabular}

Ortaköy işletmesi, yatırım amaçlı gayrimenkule almış olduğu sabit kıymet için amortisman tutarını gayrimenkulün yıpranması kiralık olarak kullanılmasına bağlı olmadığ için yıllık olarak hesaplayacaktır ve "207 Birikmiş Amortisman Hesabını" kullanacaktır. Faaliyet kiralaması faaliyeti bir hizmet olduğu için, kiralık döneme isabet eden tutar

\footnotetext{
- Iskonto oranı olarak kullanılan yıllık zımmi faiz oranı yüzde 12 (aylık zımmi faiz oranı yüzde 1)
}

- 207 Birikmiş Amortisman ve 209 Verilen Avanslar Hesabi; 26.12.1992 tarihli 21447 sayılı Resmi Gazete'de yayınlanan 1seri nolu Muhasebe Sistemi Uygulama Genel Tebliği incelendiği zaman 25 Maddi Duran Varlıklar grubunda 257 Birikmiş Amortisman, 26 Maddi Olmayan Duran Varlıklar grubunda 268 Birikmiş İtfa Payları, 27 Özel Tükenmeye Tabii Varlıklar grubunda Birikmiş İtfa Payları isimleri ile duran varlıklar grubunda yer alan her bir grup için amortisman, itfa ve tükenme payları ayrı ayrı sınıflandırılmıştır. Tebliğ'de aynı tür sınıflandırma verilen avanslar hesapları içinde geçerlidir. 259 Verilen Avanslar, 269 Verilen Avanslar, 279 Verilen Avanslar gibi. Tebliği muhasebenin temel kavramlarından özün önceliği kavramı gereği ilgili sınıflandırmaları gerçekleştirmektedir. Çalışmamızda yatırım amaçlı gayrimenkullerin 20 Alım Satım ve Yatırım Amaçlı Gayrimenkuller grubunda yer alması önerilmektedir. 20 Alım Satım ve Yatırım Amaçlı Gayrimenkuller grubu için özün önceliği kavramı gereği yapılan sınıflandırma çerçevesinde ilgili grupta yer alan varlıklardaki yıpranma payı için 207 Birikmiş Amortisman hesabının kullanılması önerilmektedir. Eğer yine aynı grupta yer alan gayrimenkuller için avans verilmesi durumunda da 209 Verilen Avanslar hesabının kullanılması önerilmektedir. Önerilen hesapların kullanılması 1seri nolu Muhasebe Sistemi Uygulama Genel Tebliğ’de yer alan sınıflandırma bütünlüğünü sağlamak için önemlidir. 
amortisman tutarı "Hizmet Üretim Maliyeti" hesabında", kalan kısım ise daha önce firma tarafından kullanıldığı için "Genel Yönetim Gideri" hesabında yer alacak ve "Gelir Tablosu" ile ilişkilendirilecektir.

Bir işletmesi dönemsellik kavramı gereği dönem ayrıştırıcı hesapları kullanırken alacak ve borç ile gelirlerinin kayıtlarını, yevmiye kayıt tarihi itibariyle gerçeğe uygun değerlerini dikkate alarak yapıyorsa; 236 ve 136 Diğer Çeşitli Alacaklar Hesabı için aktif düzenleyici hesap olan 237, 137 Diğer Alacak Senet. Reeskontu (-) Hesabının alt hesaplarında Sözleşmeye Dayalı Çeşitli Alacaklar Reeskontu Tali Hesabında; dönem ayrıştırıcı hesap olan 482 Gelecek Yıllara Ait Gelirler ile 382 Gelecek Aylara ait Gelirler için boş olan ve pasif düzenleyici hesap olarak 483 Kazanılmamış Faaliyet Kiralaması Gelirleri İskonto Tutarı ve 383 nolu Kazanılmamış Faaliyet Kiralaması Gelirleri İskonto Tutarı Hesapları kullanılabilir.436 ve 336 Diğer Çeşitli Borçlar Hesapları için pasif düzenleyici hesap olan 437, 337. Diğer Borç Senetleri Reeskontu(-) Hesabının alt hesaplarında Sözleşmeye Dayalı Çeşitli Borçlar Reeskontu Tali Hesabında, 182, 282. Faaliyet Kiralamasından Gelecek Aylara Ait Giderler Hesapları için aktif düzenleyici hesap olan ve 183 Ertelenmiş Faaliyet Kiralaması Giderleri İskonto Tutarı(-), 283.Ertelenmiş Faaliyet Kiralaması Giderleri İskonto Tutarı (-) hesapları kullanılabilir.

\section{Ortaköy İşletmesinin Muhasebe Kaydı}

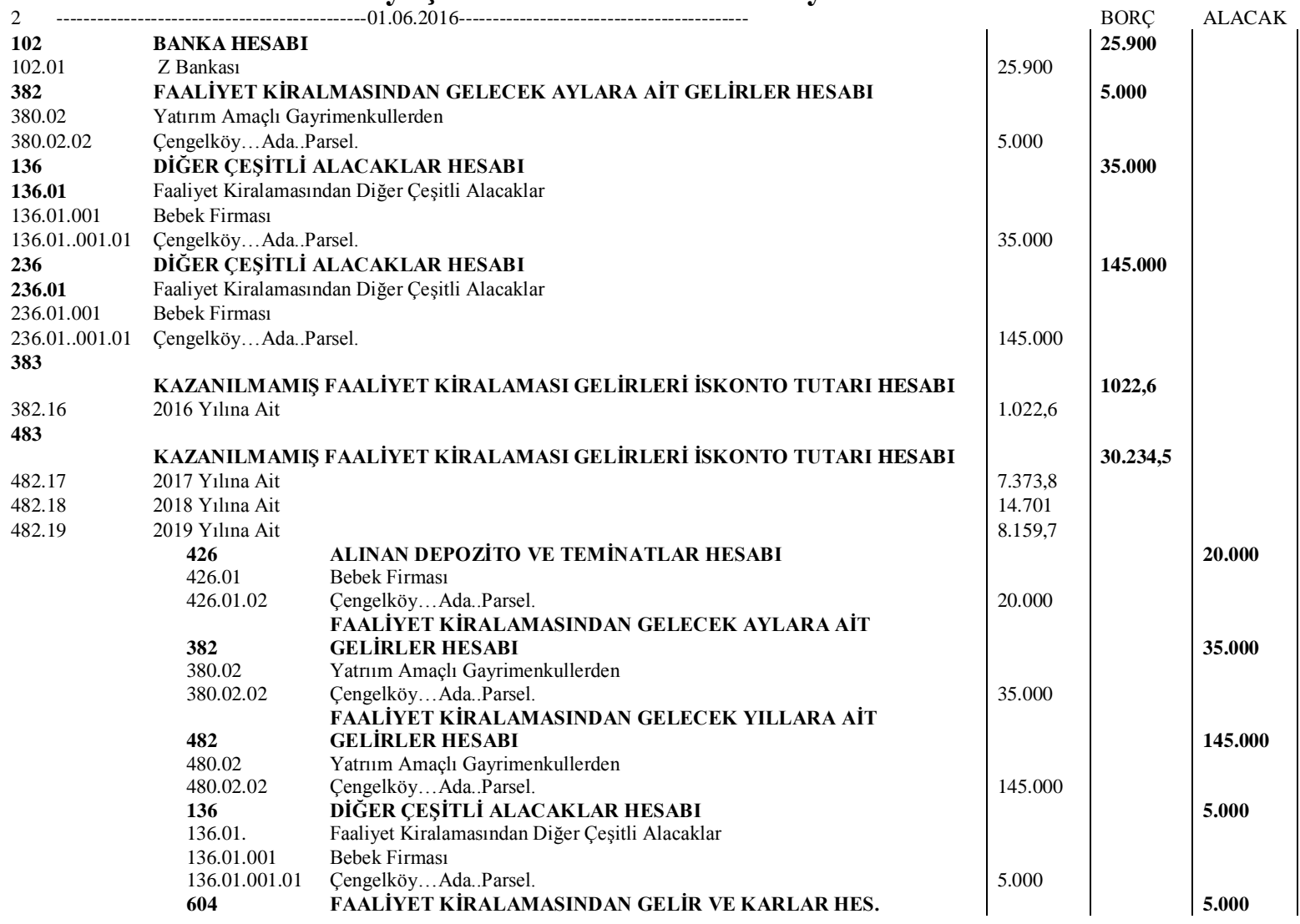

\footnotetext{
• Ortaköy işletmesinin ana faaliyet konusu faaliyet kiralaması yapmak değildir. Fakat faaliyet kiralaması ile önemli bir gelir elde etmektedir. Faaliyet kiralaması, kiralamaya konu varlığa ait kiralama süresinin depolanamaması sebebiyle bir hizmet faaliyetidir. İlgili hizmetten elde edilen gelirler normalde hizmet satışı olarak muhasebeleştirilmelidir. Fakat genel uygulamalarda kiralama işlemlerinde dönem ayırıcı hesapların kullanılmaktadır. Çalışmamızda genel uygulamalar çerçevesinde hazırlanmıştır. Fakat faaliyet kiralamasına konu varlığa ait katlanılan fedakârlıkları, özün önceliği kavramı gereği ayrı takip etmek için Faaliyet Kiralama Hizmeti Üretim Maliyeti hesabının kullanılması önerilmiştir.
} 


\begin{tabular}{|c|c|c|c|}
\hline 604.01 & Yatırım Amaçlı Gayrimenkul Faaliyet Kiralaması Gelirleri & & \\
\hline 604.01 .02 & Çengelköy...Ada..Parsel. & 5.000 & \\
\hline 391 & HESAPLANAN KDV HESABI & & 900 \\
\hline 391.01 & Haziran 2016 & 900 & \\
\hline 137 & DİĞER ALACAK SENETLERİ REESKONTU HESABI & & \\
\hline 137.02 & Faaliyet Kiralamasından Diğer Alacakların Reeskontu & & $1.022,6$ \\
\hline 137.02.16 & 2016 Yılına Ait Diğer Alacaklar & $1.022,6$ & \\
\hline 237 & DİĞER ALACAK SENETLERİ REESKONTU HESABI & & $\mathbf{3 0 . 2 3 4 , 5}$ \\
\hline $\begin{array}{l}\text { 237.02. } \\
237.02 .17\end{array}$ & $\begin{array}{l}\text { Faaliyet Kiralamasından Senetsiz Diğer Alacakların Reeskontu } \\
2017 \text { Yilına Ait Diğer Alacaklar }\end{array}$ & 73738 & \\
\hline 237.02 .18 & 2018 Y1lına Ait Diğer Alacaklar & 14.701 & \\
\hline 237.02.19 & 2019 Yilına Ait Diğer Alacaklar & $8.159,1$ & \\
\hline e Tahsilatın & asebeleștirilmesi & & \\
\hline
\end{tabular}

\section{Bebek İşletmesinin Muhasebe Kaydı}

\begin{tabular}{|c|c|}
\hline 1 & 1.6 .2016 \\
\hline $\begin{array}{ll}226 \\
226.01\end{array}$ & $\begin{array}{l}\text { VERİLEN DEPOZITO VE TEMİNATLAR HESABI } \\
\text { Çengelköy....Ada..Parsel. }\end{array}$ \\
\hline 182 & FAALIYET KİRALAMASINDAN GELECEK AYLARA AİT GIDERLER HESABI \\
\hline 180.02.02 & Çengelköy...Ada..Parsel. \\
\hline 280 & FAALIYET KİRALMASINDAN GELECEK YILLARA AİT GİDERLER HESABI \\
\hline 280.02.02 & Çengelköy...Ada..Parsel. \\
\hline 770 & $\begin{array}{l}\text { GENEL YÖNETIM GIDERİ HESABI } \\
\text { Çeșitli }\end{array}$ \\
\hline 770.04 & Giderler \\
\hline 770.04 .001 & Kira Gideri \\
\hline 191 & İNDİRILLECEK KDV HESABI \\
\hline 191.01 & Haz.16 \\
\hline 329 & DİĞER TİCARİ BORÇLAR HESABI \\
\hline 329.01 & Faaliyet Kiralamasından Diğer Ticari Borçlar \\
\hline 329.01 .001 & Ortaköy Firması \\
\hline 337 & DİĞER BORÇ SENETLERİ REESKONTU HESABI \\
\hline 337.02 & Faaliyet Kiralaması Sözleşmesine Dayalı Diğer Çeșitli Borçların Reeskontu \\
\hline 337.02 .016 & 2016 Yilına Ait \\
\hline 437 & DİĞER BORÇ SENETLERİ REESKONTU HESABI \\
\hline 437.02 & Faaliyet Kiralaması Sözleșmesine Dayalı Diğer Çeşitli Borçların Reeskontu \\
\hline 437.02.017 & 2017 Yilına Ait \\
\hline 437.02.018 & 2018 Y1lına Ait \\
\hline 437.02.019 & 2019 Yllina Ait \\
\hline 102 & BANKA HESABI \\
\hline 102.01 & V Bankası. \\
\hline 329 & DİĞER TİCARİ BORÇLAR HESABI \\
\hline 329.01 & Faaliyet Kiralamasından Diğer Ticari Borçlar \\
\hline 329.01 .001 & Ortaköy Firması \\
\hline 429 & DİĞER TİCARİ BORÇLAR HESABI \\
\hline 429.01 & Faaliyet Kiralamasından Diğer Ticari Borçlar \\
\hline 429.01 .001 & Ortaköy Firmas1 \\
\hline 180 & FAALIYYET KİRALAMASINDAN GELECEK AYLARA AITT GIDERLER \\
\hline 180.02 .02 & Çengelköy..Ada..Pparsel \\
\hline 383 & ERTELENMISS FAALIYYT KİRALAMASI GIDERLERİ İSKONTO TUTARI \\
\hline 382.16. & 2016 Y1lina Ait \\
\hline 483 & ERTELENMISS FAALIYET KİRALAMASI GİDERLERİ ISSKONTO TUTARI \\
\hline 482.17 & 2017 Yilina Ait \\
\hline 482.18 & 2018 Yilına Ait \\
\hline 482.19 & 2019 Y1lına Ait \\
\hline & Kira Sözleșmesinin ve Ödemelerin Muhasebeleștirilmesi \\
\hline
\end{tabular}

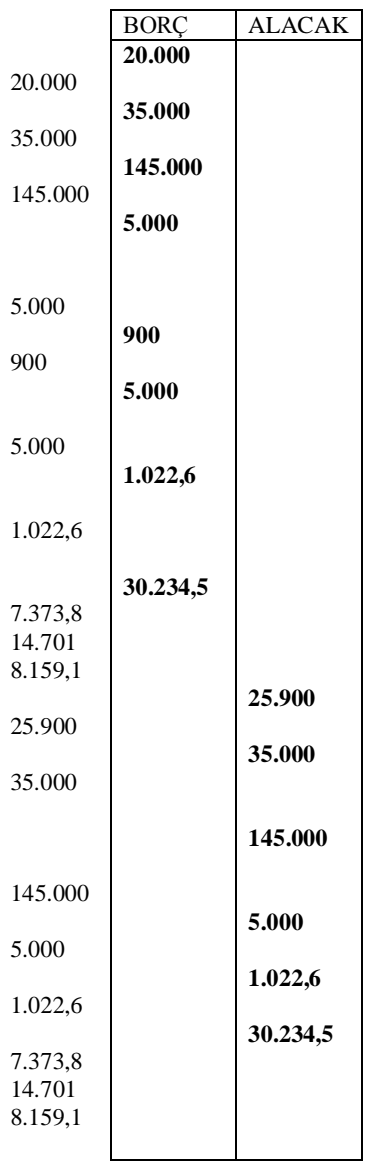

\begin{tabular}{|c|c|c|}
\hline 1 & & 1.6 .2016 \\
\hline 264 & ÖZEL MALIYYTLER HESABI & \\
\hline 264.01 & Çengelköy...Ada, ...Parsel & \\
\hline 191 & İNDİRILECEK KDV HESABI & \\
\hline 191.07 & Temmuz İnd. KDV & \\
\hline \multirow[t]{5}{*}{320} & SATICILAR & \\
\hline & 320 & SATICILAR HESABI \\
\hline & 102 & BANKA HESABI \\
\hline & 102.01 & V Bankası \\
\hline & ...Numaralı Fatura Tahakkuku ve Ödemesi & \\
\hline
\end{tabular}

\begin{tabular}{|l|l|l|}
\cline { 2 - 3 } & BORÇ & ALACAK \\
\cline { 2 - 3 } 35.000 & $\mathbf{3 5 . 0 0 0}$ & \\
6.300 & $\mathbf{6 . 3 0 0}$ & \\
& $\mathbf{4 1 . 3 0 0}$ & \\
& & $\mathbf{4 1 . 3 0 0}$ \\
41.300 & & $\mathbf{4 1 . 3 0 0}$ \\
\hline
\end{tabular}

Özel Maliyet olarak kayıt edilen tutarı Bebek işletmesi kira süresi içinde itfa edecektir. 2016 yılında kıst amortisman uygulayacak ve “268 Birikmiş İtfa Payları Hesabı”"nı kullanacaktır. İlgili döneme isabet eden itfa payları "Genel Yönetim Gideri" hesabında toplanacak ve "Gelir Tablosu" ile ilişkilendirilecektir. 
Not-1; Eğer Bebek işletmesi ve Ortaköy işletmesi birbiri diğerinin bağlı ortaklığ konumunda ise ve konsolide mali tablo kapsamında raporlama zorunlulukları var ise; solo mali tablolarında yukarıdaki gibi yevmiye kayıtlarını tutmuş olsalar bile, ana ortaklık konsolide mali tablosun da ilgili yatırım amaçlı gayrimenkul hesabında yer alan tutar, binalar hesabında gösterilmeli ve amortisman tutarı 257 Birikmiş Amortisman Hesabında takip edilmelidir. Toplam tutar genel yönetim gideri hesabı kullanılarak Gelir Tablosu ile ilişkilendirilmelidir. Bebek işletmesinin Özel Maliyet hesabında takip ettiği tutar ise ya bakım ve onarım harcamaları olarak yönetim gideri olarak tamamen muhasebeleştirmeli ya da ilgili bakım onarımın amortisman süresi sabit kıymetin amortisman süresinden kısa olduğu için Binalar hesabının alt hesap kalemlerinde muhasebeleştirilerek amortisman tutarını Bebek işletmesinin amortisman hesaplama yöntemi doğrultusunda hesaplayarak genel yönetim giderleri hesabında muhasebeleştirmeli ve gelir tablosu ile ilişkilendirmelidir. Gelecek aylara ait gelirler ve gelecek yıllara ait gelirler ile gelecek aylara ait giderler ve gelecek yıllara ait giderler mahsup edilecektir. Banka ve firmaların karşılık ticari işlemine konu olan KDV hesapları mahsup edilecektir.

Not -2; Ortaköy işletmesi ilgili müstakil binayı finansal kiralama sözleşmesi* ile kiralamış olsaydı, ilgili binayı sözleşme tarihinden itibaren finansal durum tablosunun dışına çıkarmak zorundadır. Bebek işletmesi 'de sözleşmeye dayalı olarak ilgili müstakil binayı kendi aktifinde binalar hesabına alması gereklidir. Yapmış olduğu bakım onarım maliyetlerin özel maliyet hesabında takip etmek yerine bina maliyetine eklemelidir. İlgili binanın amortismanını da kendisi ayırmalıdır.

ÖRNEK VAKA 2; Haliç işletmesi 2 Mayıs 2016 tarihinde 500.000 TL bedelli bir İstanbul Selimpaşa'daki ... Ada... Parsel deki arsayı, değerinin zamanla artmasını beklediği uzun vadeli bir yatırım olarak, bir şahıstan, 300.000 TL özkaynağı ve aylık nominal faizi \% 1 olan, ay sonlarında ödemeli 24 ay vadeli 200.000 TL için çalışmış olduğu Z bankasından kullanmış olduğu ipoteğe dayalı kredi ile satın almıştır. Mal Bedelini Z bankasından yapmış olduğu bir havale ile ödemiştir. Bankaya expertiz değeri olarak 600 TL, tapu masrafi 10180 TL, komisyon masrafı olarak aracılara 10.000 TL +KDV nakden ödemiştir. Arsanın gerçeğe uygun değeri aşırı maliyete veya çabaya katlanılmadan sürekli ölçebilmektedir.

\section{Olağan Anüitenin Bugünkü Değeri = Taksit Tutarı [ 1- [1/(1+i) $) / \mathbf{i}]]$}

$$
200.000=A[1-[1 /(1+0,01) 24) / 0,01]] \quad \text { Taksit Tutarı }=9.415 \text { TL/Ay }
$$

\footnotetext{
* Bir kiralamanın finansal kiralama mı faaliyet kiralaması mı olduğunun tespitinde, sözleşmenin şeklinden ziyade işlemin özü esas alınır. Finansal kiralamanın dışındaki kiralamalar faaliyet kiralamasıdır. Faaliyet kiralamasında; mal sahibi (kiraya veren) mala sahip olmanın verdiği risk ve getirilerin tümünü elinde bulundurur. Normalde, birlikte ya da tek başlarına, bir kiralama işleminin finansal kiralama olarak sınıflandırılmasına neden olabilecek durumlara örnekler aşağıdaki gibidir:

(a) Kiralanan varlığın mülkiyetinin kiralama süresinin sonunda kiracıya geçmesi.

(b) Kiracıya, kiralanan varlığı, buna ilişkin opsiyonun kullanım tarihinde oluşması beklenen gerçeğe uygun değerinden çok daha düşük bir bedelle satın alma opsiyonu verilmesi nedeniyle, kiralama sözleşmesinin başlangıcı itibarıyla kiracı tarafından bu opsiyonun kullanılacağının makul şekilde kesin olması.

(c) Mülkiyet, kiracıya geçmeyecek dahi olsa, kira süresinin, kiralanan varlığın ekonomik ömrünün büyük bir bölümünü kapsamasi.

(d) Kiralama sözleşmesinin başlangıcı itibarıyla, asgari kira ödemelerinin bugünkü değerlerinin, en azından, kiralanan varlı̆̆ın gerçeğe uygun değerine önemli ölçüde eşit olması.

(e) Kiralanan varlığın, üzerinde büyük değişiklikler yapılmadığı sürece, sadece kiracı tarafından kullanılabilecek özel bir yapida olmasi.
} 
The Journal of Accounting and Finance

April/2018

\begin{tabular}{|c|c|c|c|c|c|}
\hline Taksit Sayısı & Taksit Tutarı & $\begin{array}{c}\text { Aylık Nominal } \\
\text { Faiz Oranı }\end{array}$ & Faiz Ödemesi & Anapara Ödemesi & Kalan Anapara \\
\hline 0 & 0 & & 0 & 0 & 200.000 \\
\hline 1 & 9.415 & $0,01^{\star}$ & 2.000 & 7.415 & 192.585 \\
\hline 2 & 9.415 & 0,01 & 1.926 & 7.489 & 185.096 \\
\hline 3 & 9.415 & 0,01 & 1.851 & 7.564 & 177.532 \\
\hline 4 & 9.415 & 0,01 & 1.775 & 7.640 & 169.892 \\
\hline 5 & 9.415 & 0,01 & 1.699 & 7.716 & 162.176 \\
\hline 6 & 9.415 & 0,01 & 1.622 & 7.793 & 154.383 \\
\hline 7 & 9.415 & 0,01 & 1.544 & 7.871 & 146.512 \\
\hline 8 & 9.415 & 0,01 & 1.465 & 7.950 & 138.562 \\
\hline Toplam & 75.320 & & 12.417 & 61.438 & \\
\hline 9 & 9.415 & 0,01 & 1.386 & 8.029 & 130.532 \\
\hline 10 & 9.415 & 0,01 & 1.305 & 8.110 & 122.423 \\
\hline 11 & 9.415 & 0,01 & 1.224 & 8.191 & 114.232 \\
\hline 12 & 9.415 & 0,01 & 1.142 & 8.273 & 105.959 \\
\hline 13 & 9.415 & 0,01 & 1.060 & 8.355 & 97.604 \\
\hline 14 & 9.415 & 0,01 & 976 & 8.439 & 89.165 \\
\hline 15 & 9.415 & 0,01 & 892 & 8.523 & 80.642 \\
\hline 16 & 9.415 & 0,01 & 806 & 8.609 & 72.033 \\
\hline 17 & 9.415 & 0,01 & 720 & 8.695 & 63.338 \\
\hline 18 & 9.415 & 0,01 & 633 & 8.782 & 54.557 \\
\hline 19 & 9.415 & 0,01 & 546 & 8.869 & 45.687 \\
\hline 20 & 9.415 & 0,01 & 457 & 8.958 & 36.729 \\
\hline 21 & 9.415 & 0,01 & 367 & 9.048 & 27.681 \\
\hline 22 & 9.415 & 0,01 & 277 & 9.138 & 18.543 \\
\hline 23 & 9.415 & 0,01 & 185 & 9.230 & 9.314 \\
\hline \multirow[t]{2}{*}{24} & 9.415 & 0,01 & 101 & 9.314 & 0 \\
\hline & 150.640 & & 13.543 & 138.562 & \\
\hline Toplam & 225.960 & & 25.960 & 200.000 & \\
\hline
\end{tabular}

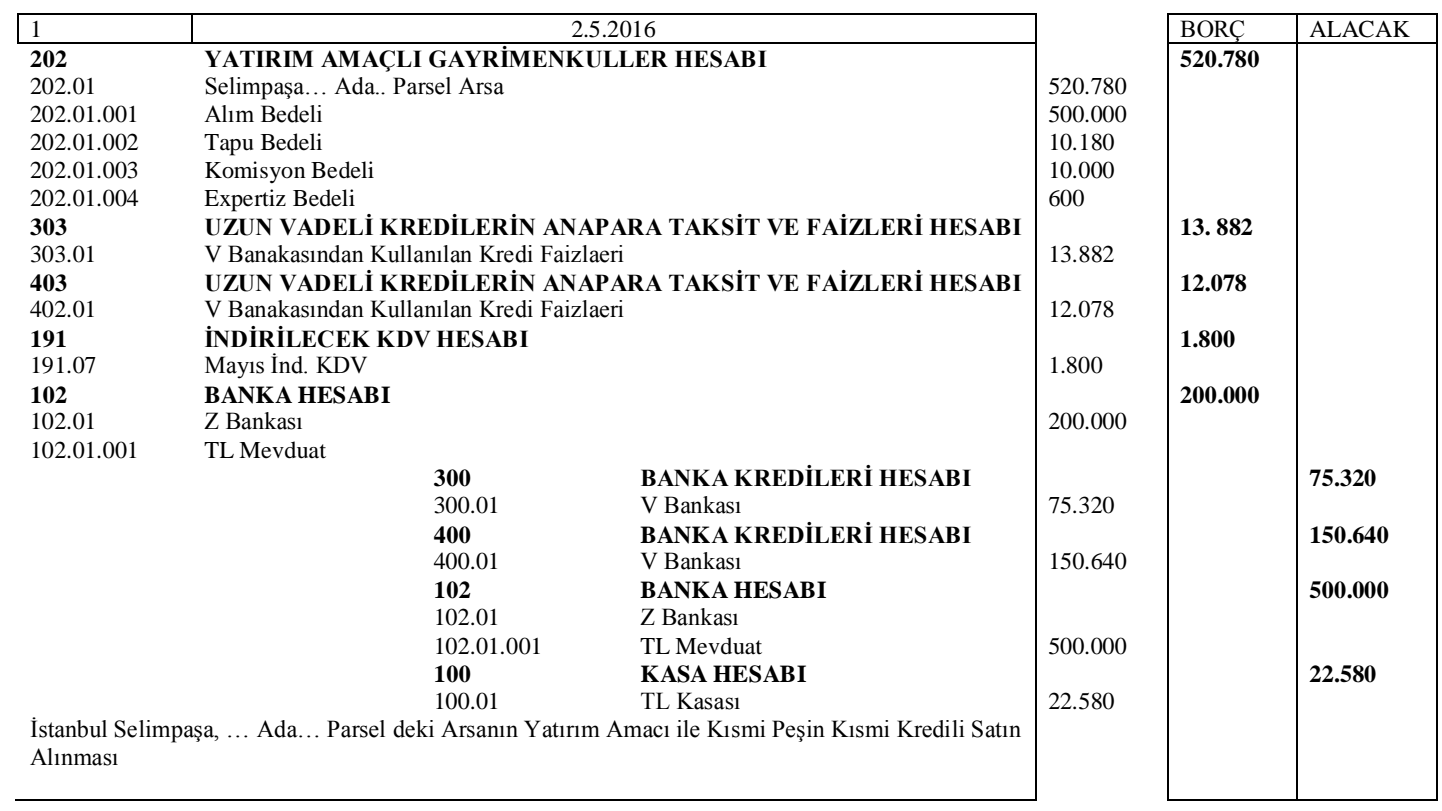

- İskonto oranı olarak kullanılan yıllık zımmi faiz oranı yüzde 12 (aylı zımmi faiz oranı yüzde 1) 
İlgili arsa yatırımı, gerçeğe uygun değeri aşırı maliyete veya çabaya katlanılmadan sürekli ölçebilme ve uzun vadeli yatırım amacıyla edinildiği için yatırım amaçlı gayrimenkul hesabı içerisinde takip edilmiştir. İlgili arsa yatırımı için amortisman ayrılmayacaktır. Arsa alımı sebebiyle katlanılan finansman giderleri arsa maliyetine dahil edilmeyecek ve gelir tablosu ile ilişkilendirilecektir ${ }^{1 *}$.

ÖRNEK VAKA 3; Hamsiköy işletmesi, 12 Kasım 2017 tarihinde Hamseköydeki fabrika binasındaki faaliyetini durdurmuş ve kiraya vermeye karar vermiştir. Fabrika binasının defter değeri 400.000 (Arsa Bedeli; 130.000, Yapı Bedeli; 270.000), Birikmiş Amortisman1 96.000 TL, Yeniden Değerleme Fonu; 34.000 TL'dir.

18.Kasım 2017 tarihinde Hamsiköy işletmesi kiralama öncesi Eva Gayrimenkul Değ. A.Ş.'den ilgili fabrika binası için değerleme raporu talep etmiştir. 21 Kasım 2017 tarihli değerleme raporuna göre; Fabrika binasının değeri; arsa değeri; 410.000, yapı değeri 250.000 TL olmak üzere, toplam 660.000 TL olarak tespit edilmiştir.

\begin{tabular}{|c|c|c|c|c|c|}
\hline 1 & \multicolumn{2}{|c|}{$\begin{array}{c}12.11 .2017 \\
\text { YATIRIM AMACLI GAYRİMENKULLER HESABI }\end{array}$} & & BORÇ & ALACAK \\
\hline $\begin{array}{l}\mathbf{2 0 2} \\
202.01 . \\
202.01 .010 \\
202.01 .020 \\
\mathbf{2 5 7} \\
\mathbf{2 5 7 . 0 1}\end{array}$ & $\begin{array}{l}\text { YATIRIM AMAÇLI G } \\
\text { Hamsi Köy.... Ada, ... P } \\
\text { Arsa Bedeli } \\
\text { Yapı Bedeli } \\
\text { BİRIKMIŞ AMORTIS I } \\
\text { Hamsi Köy.... Ada, ... P } \\
\text { MADDİ DURAN VARI } \\
\text { HESABI } \\
\text { Hamsi Köy.... Ada, ... P } \\
\text { Değer Artışı } \\
\qquad \mathbf{2 5 2} \\
252.01 \\
252.01 .010 \\
252.01 .010 .011 \\
251.01 .010 .012 \\
252.01 .020 . \\
252.01 .020 .021 \\
252.01 .021 .022\end{array}$ & $\begin{array}{l}\text { AYRİMENKULLER HESABI } \\
\text { arsel Fabrika Binası } \\
\text { MAN HESABI } \\
\text { arsel Fabrika Binası Birikmiş Amortismanı } \\
\text { IK YENIDEN DEĞERLEME FONU } \\
\text { arsel Fabrika Binası Yeniden Değerleme } \\
\text { BİNALAR HESABI } \\
\text { Hamsi Köy.... Ada, ... Parsel Fabrika } \\
\text { Binası } \\
\text { Arsa Bedeli } \\
\text { Satın Alma Bedeli } \\
\text { Yeniden Değerleme Değer Artışı } \\
\text { Yapı Bedeli } \\
\text { İnşa Maliyeti } \\
\text { Yeniden Değerleme Değer Artışı }\end{array}$ & $\begin{array}{l}120.000 \\
10.000 \\
246.000 \\
24.000\end{array}$ & 270.000 & 400.000 \\
\hline
\end{tabular}

Not 1 ; Haliç işletme arsayı, satın alma tarihi itibariyle belirlenmemiş fakat gelecekteki bir kullanım için satın almış olsaydı da; gayrimenkulün geliştirilmek amacıyla kullanılması da gelecekte verilecek bir yatırım kararı olması sebebiyle, yatırım amaçlı gayrimenkuller içerisinde muhasebeleştirilecektir.

Not 2 ; Haliç işletmesi arsayı; belirli bir kar marjı ile bütününü veya küçük parsellere ayırarak satmak amacıyla, ana faaliyeti kapsamı dışında olmasına rağmen, elde edinmişse, Satış Amaçlı Gayrimenkuller hesabında muhasebeleştirmelidir. Satış amaçlı gayrimenkuller Finansal Durum Tablosunda (Bilanço) dönen varlıklar 1.nci toplamından sonra yer almalı ve dönen varlıklar ikinci toplam kapsamında olmalıdır. Muhasebe uygulamaları genel tebliği doğrultusunda hazırlanan hesap planında dönen varlıklar grubu içerisinde satış amaçlı gayrimenkuller adıyla bir hesap yoktur. Bu nedenle gerektiğinde boş olan 200 grubu içerisinde 203 Satış Amaçlı Gayrimenkul adıyla bir hesap açılabilir ve burada takip edilebilir. Fakat raporlama anında hesapta bulunan tutarı duran varlıklar toplamından çıkartılmalı ve dönen varlıklar birinci toplamından sonra mali tablolara yansıtılmalıdır. Çünkü ilgili tutarın dönen varlıklar da yer alması işletmenin finansal rasyoları açısından da önemlidir.

Not 3; Haliç işletmesi arsayı; belirli bir kar marjı ile bütününü veya küçük parsellere ayırarak satmak amacıyla, ana faaliyet kapsamında elde etti ise, ilgili arsayı 152 Ticari Mallar hesabında takip etmelidir. 


\begin{tabular}{|c|c|c|c|c|c|}
\hline 2 & & 21.11 .2017 & & BORÇ & ALACAK \\
\hline 202 & \multicolumn{2}{|c|}{ YATIRIM AMAÇLI GAYRİMENKULLER HESABI } & & 390.000 & \multirow{10}{*}{390.000} \\
\hline 202.01. & \multicolumn{2}{|c|}{ Hamsi Köy.... Ada, ... Parsel Fabrika Binası } & & & \\
\hline 202.01.011 & \multicolumn{2}{|c|}{ Arsa Bedeli Değer Artışı } & 290.000 & & \\
\hline 202.01.021 & \multicolumn{2}{|c|}{ Yapı Bedeli Değer Artışı } & 100.000 & & \\
\hline & & YATIRIM AMAÇLI GAYRİMENKULLER & & & \\
\hline & 525 & DEĞER ARTIŞ HESABI* & & & \\
\hline & 525.01 & Hamsi Köy.... Ada, ... Parsel Fabrika Binası & & & \\
\hline & 525.01 .001 & Gerçeğe Uygun Değer Artışı & & & \\
\hline & 525.01 .001 .001 & Arsa Gerçeğe Uygun Değer Artışı 290.000 & & & \\
\hline & 525.01 .001 .002 & Bina Gerçeğe Uygun Değer Artışı 290.000 & & & \\
\hline \multicolumn{3}{|c|}{$\begin{array}{l}\text { 18.11.2017 Tarihli ...... Sayılı EVA Değerleme Raporu'na Göre Gerçeğe Uygun } \\
\text { Değerin Kayıtlara Alınması }\end{array}$} & & & \\
\hline
\end{tabular}

ÖRNEK VAKA 4; Suadiye işletmesi yap-sat inşaat işiyle uğraşmaktadır. 10 Aralık 2017 tarihinde Kozyatağı'nda ... Ada, ... parsel yapmış olduğu bir inşaattaki 4. Numaralı dükkanı satmaktan vazgeçerek kiralama kararı almıştır. 10 Aralık 2017 tarihinde Kozyatağı'nda ... Ada, ... parseldeki 4 numaralı dükkanın arsa bedeli 1.200.000 TL, inşa maliyeti 900.000 TL'dir. 12 Aralık 2017tarihinde Suadiye işletmesi, Eva Gayrimenkul Değ. A.Ş.'den ilgili dükkan için değerleme raporu talep etmiştir. 16 Aralık 2017 tarihli değerleme raporuna göre; Dükkanın değeri; arsa değeri; 1.800.000, yapı değeri 940.000 TL olmak üzere, toplam 2.740.000 TL olarak tespit edilmiştir. 28 Aralık 2017 tarihinde, Kira Süresi 1 Ocak 2018 tarihinden itibaren başlamak üzere Z bankasına aylık $10.000 \mathrm{TL}+\% 18 \mathrm{KDV}$ bedelle 5 Yıllık süre ile kiraya vermiştir. 30.000 TL depozito almıştır. Kira artış oranı yıllık \% 8'dir. Suadiye işletmesi alacak borçlarını değerlerken kullanım olduğu iskonto oranı olarak kullanılan yıllık zımmi faiz oranı yüzde 6 (aylık zımmi faiz oranı binde 5), , aylık nominal 0,005'dır. 1 Ocak 2018 tarihinde 1 aylık kira bedeli olarak 10.000 TL + \% 18 KDV'si Suadiye işletmesinin bankadaki mevduat hesabına yatırılmıştır. 1 Şubat 2018 tarihinde 1 aylık kira bedeli olarak 10.000 TL + \% 18 KDV'si Suadiye işletmesinin bankadaki mevduat hesabına yatırılmıştır. İşletme dönemsellik kavramı gereği dönem ayrıştırıcı hesapları kullanırken alacak, borç ve gelirlerini yevmiye kayıt tarihi itibariyle gerçeğe uygun değerlerini dikkate alarak yevmiye kayıtlarını yapmaktadır.

\footnotetext{
• 525 Yatırım Amaçlı Gayrimenkuller Değer Artışı Hesabı; Stoklardan, gerçeğe uygun değer esasından izlenecek olan yatırım amaçlı gayrimenkullere yapılan bir transferde; gayrimenkulün transfer tarihindeki gerçeğe uygun değeri ile daha önce belirlenmiş olan defter değeri arasındaki fark kâr veya zarar olarak muhasebeleştirilir. Burada neden bir özkaynak hesabına kayıtlandı sorusu sorulabilir. Kurumların hazırlaması gereken gelir kalemleri olağan faaliyetlerden kar ve zararı ile diğer kapsamlı gelirlerden oluşmaktadır. Ya da tek kapsamlı gelir tablosunda ilgili bilgiler yer almaktadır. Sadece sınıflandırma sebebiyle varlığın gerçeğe uygun değeri ile defter değeri arasında farkın olağan faaliyetlerden kar ve zararın içerisinde gösterilmesi olağan kar ve zararın hatalı yorumlanmasına neden olur. Kurumlar olağan faaliyetlerinden gelirlerini yüksek göstermek amacıyla yatırımcıları yanlış bilgilendirebilir. Vergiden önceki kar ile hesaplanabilen tüm finansal rasyoları etkileyebilir ve yanlış karar almaya sebep olabilir. Fakat ilgili fark bir gelirdir, fakat gelirin realize olduğu an kiralama sözleşmesinin devredildiği andır. Fakat yine de realize olmadan gelir tablosu ile ilişkilendirilmesi için diğer kapsamlı gelirlerde gösterilmesi tesis edilmelidir. Diğer kapsamlı gelirler arasında yer almasını sağlamak amacı ile 525 Yatırım Amaçlı Gayrimenkuller Değer Artışı hesabı önerilmiştir. Değer artışı finansal durum tablosunda yer alan özkaynaklarda sermaye grubunda takip edilmeli, kapsamlı gelir tablosunda ise diğer kapsamlı gelirler arasında raporlanmalıdır (TMS 40, m:62/ii). İlgili değer artışı, varlığın elden çıkarılması anında sürekli faaliyetlerden kar ve zarar grubuna dahil edilmelidir. Yatırım amaçlı gayrimenkuller, alım satım amaçlı bir gayrimenkul değildir. Alım satım amaçlı gayrimenkul kısa vadeli bir amaç içermektedir. Yatırım amaçlı gayrimenkul ise daha uzun vadeli bir amacı bünyesinde barındırmaktadır. Bu ayrımın iyi yapılması gerekir. Buna benzer bir uygulama 11 Menkul Kiymetler ve 24 Mali Duran Varlıklar hesap gruplarının ayrımında da görülebilir. Örneğin \% 18 hissesine sahip olduğunuz bir ortaklık payınızı kısa dönemli, alım satım amacı ile muhasebeleştiriyorsanız 11 Menkul Kıymetler grubunda 110 Hisse Senetleri hesabında takip edebilir ve gerçeğe uygun değeri ile defter değeri arasındaki farkı olağan kar ve zarar ile ilişkilendirebilirsiniz. Fakat aynı ortaklık payınızı uzun vadeli yatırım amacı ile muhasebeleştiriyorsanız, 24 Mali Duran Varlıklar grubunda 240 Bağlı Menkul Kıymetler hesabında sınıflandırabilir ve varlığın gerçeğe uygun değeri ile defter değeri arasındaki farkı özkaynak grubunda sermaye yedekleri arasında takip edersiniz fakat kapsamlı gelir tablosunda diğer kapsamlı gelirler arasında raporlayabilirsiniz.
} 


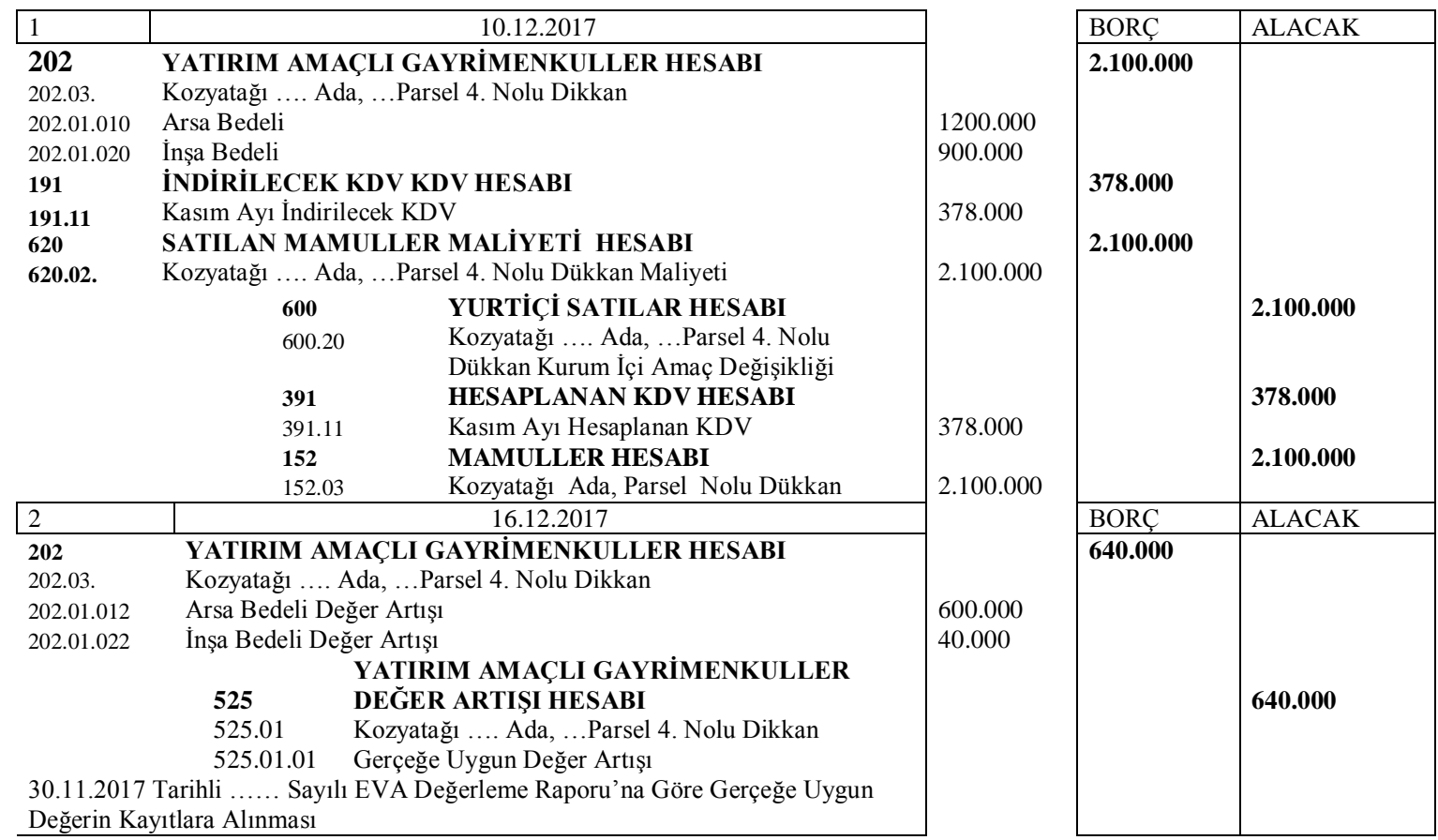

\begin{tabular}{|c|c|c|c|c|c|c|c|c|c|c|c|c|c|}
\hline \multicolumn{14}{|c|}{ MUHTEMEL NAKİT GİRIŞLERİNİN BUGÜNKÜ DEĞERİNIN VE İSKONTO TUTARININ HESAPLANMASI } \\
\hline YILLAR/AYLAR & 1 & 2 & 3 & 4 & 5 & 6 & 7 & 8 & 9 & 10 & 11 & 12 & TOP. \\
\hline $\begin{array}{l}\text { 1.y1l Muhtemel } \\
\text { Nominal Nakit Girișleri }\end{array}$ & 10.000 & 10.000 & 10.000 & 10.000 & 10.000 & 10.000 & 10.000 & 10.000 & 10.000 & 10.000 & 10.000 & 10.000 & 120.000 \\
\hline İskonto Oranı & 1,0000 & 1,0050 & 1,0100 & 1,0151 & 1,0202 & 1,0253 & 1,0304 & 1,0355 & 1,0407 & 1,0459 & 1,0511 & 1,0564 & \\
\hline $\begin{array}{l}\text { 1. Yıl İskonto Edlimiş } \\
\text { Muhtemel Nakit } \\
\text { Girişleri }\end{array}$ & 10000 & 9950 & 9901 & 9851 & 9802 & 9754 & 9705 & 9657 & 9609 & 9561 & 9513 & 9466 & 116770 \\
\hline $\begin{array}{l}\text { 1. Kazanılmamış } \\
\text { Faaliyet Kiralaması } \\
\text { İskonto Tutarı }\end{array}$ & 0 & 50 & 99 & 149 & 198 & 246 & 295 & 343 & 391 & 439 & 487 & 534 & 3.230 \\
\hline $\begin{array}{l}\text { 2.y1l Muhtemel } \\
\text { Nominal Nakit Girișleri }\end{array}$ & 10.800 & 10.800 & 10.800 & 10.800 & 10.800 & 10.800 & 10.800 & 10.800 & 10.800 & 10.800 & 10.800 & 10.800 & 129.600 \\
\hline İskonto Oranı & 1,0617 & 1,0670 & 1,0723 & 1,0777 & 1,0831 & 1,0885 & 1,0939 & 1,0994 & 1,1049 & 1,1104 & 1,1160 & 1,1216 & \\
\hline $\begin{array}{l}\text { 2. Yıl İskonto Edlimiş } \\
\text { Muhtemel Nakit } \\
\text { Girişleri }\end{array}$ & 10173 & 10122 & 10072 & 10022 & 9972 & 9922 & 9873 & 9824 & 9775 & 9726 & 9678 & 9630 & 118785 \\
\hline $\begin{array}{l}\text { 2. Yıl Kazanılmamış } \\
\text { Faaliyet Kiralaması } \\
\text { İskonto Tutarı }\end{array}$ & 627 & 678 & 728 & 778 & 828 & 878 & 927 & 976 & 1.025 & 1.074 & 1.122 & 1.170 & 10.815 \\
\hline $\begin{array}{l}\text { 3.Yıl Muhtemel } \\
\text { Nominal Nakit Girişleri }\end{array}$ & 11.664 & 11.664 & 11.664 & 11.664 & 11.664 & 11.664 & 11.664 & 11.664 & 11.664 & 11.664 & 11.664 & 11.664 & 139.968 \\
\hline İskonto Oranı & 1,1272 & 1,1328 & 1,1385 & 1,1442 & 1,1499 & 1,1556 & 1,1614 & 1,1672 & 1,1730 & 1,1789 & 1,1848 & 1,1907 & \\
\hline $\begin{array}{l}\text { 3. Yıl İskonto Edlimiş } \\
\text { Muhtemel Nakit } \\
\text { Girişleri }\end{array}$ & 10348 & 10297 & 10245 & 10194 & 10144 & 10093 & 10043 & 9993 & 9943 & 9894 & 9845 & 9796 & 120835 \\
\hline $\begin{array}{l}\text { 3. Yıl Kazanılmamış } \\
\text { Faaliyet Kiralaması } \\
\text { İskonto Tutarı }\end{array}$ & 1.316 & 1.367 & 1.419 & 1.470 & 1.520 & 1.571 & 1.621 & 1.671 & 1.721 & 1.770 & 1.819 & 1.868 & 19.133 \\
\hline $\begin{array}{l}\text { 4.Yıl Muhtemel } \\
\text { Nominal Nakit Girişleri }\end{array}$ & 12.597 & 12.600 & 12.600 & 12.600 & 12.600 & 12.600 & 12.600 & 12.600 & 12.600 & 12.600 & 12.600 & 12.600 & 151.197 \\
\hline İskonto Oranı & 1,1967 & 1,2027 & 1,2087 & 1,2147 & 1,2208 & 1,2269 & 1,2330 & 1,2392 & 1,2454 & 1,2516 & 1,2579 & 1,2642 & \\
\hline $\begin{array}{l}\text { 4. Yıl İskonto Edlimiş } \\
\text { Muhtemel Nakit } \\
\text { Girişleri }\end{array}$ & 10527 & 10477 & 10425 & 10373 & 10321 & 10270 & 10219 & 10168 & 10117 & 10067 & 10017 & 9967 & 122946 \\
\hline $\begin{array}{l}\text { 4. Yıl Kazanılmamış } \\
\text { Faaliyet Kiralaması } \\
\text { İskonto Tutarı }\end{array}$ & 2.070 & 2.123 & 2.175 & 2.227 & 2.279 & 2.330 & 2.381 & 2.432 & 2.483 & 2.533 & 2.583 & 2.633 & 28.251 \\
\hline $\begin{array}{l}\text { 5.Y1l Muhtemel } \\
\text { Nominal Nakit Girişleri }\end{array}$ & 13.608 & 13.608 & 13.608 & 13.608 & 13.608 & 13.608 & 13.608 & 13.608 & 13.608 & 13.608 & 13.608 & 13.608 & 163.296 \\
\hline İskonto Oranı & 1,2705 & 1,2768 & 1,2832 & 1,2896 & 1,2961 & 1,3026 & 1,3091 & 1,3156 & 1,3222 & 1,3288 & 1,3355 & 1,3421 & \\
\hline
\end{tabular}




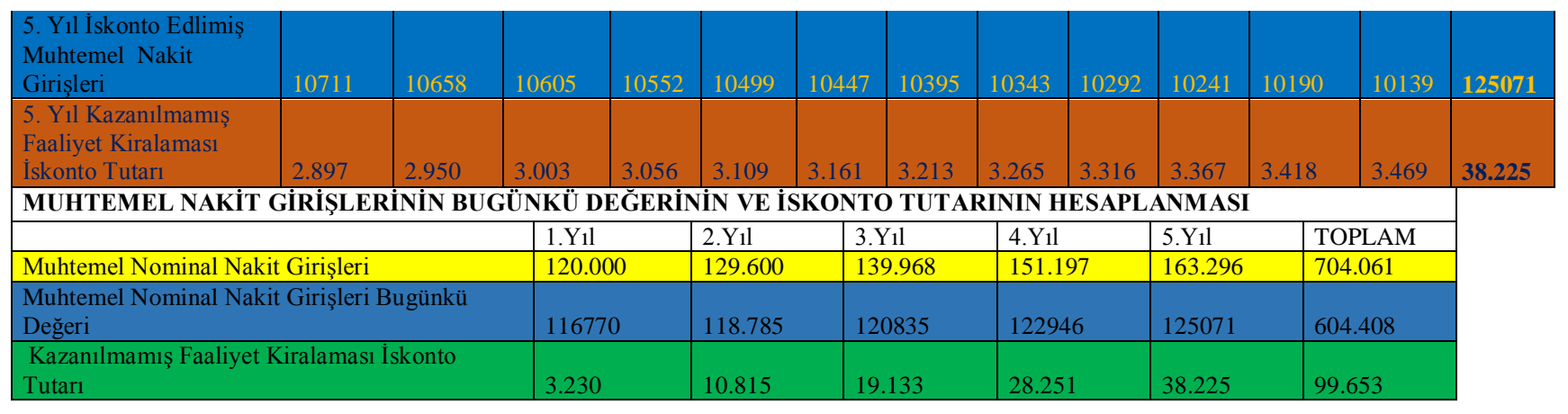

\begin{tabular}{|c|c|c|c|c|c|}
\hline 3 & & 03.02 .2017 & & BORÇ & ALACAK \\
\hline 236 & DİĞER ÇEŞ & Lİ ALACAKLAR HESABI & & 704.061 & \\
\hline 236.01 & Faaliyet Kira & ması Sözleşmesine Dayalı X Bankasından Diğer Çeşitli Alacaklar & & & \\
\hline 236.01.01 & & & 120.00 & & \\
\hline & & & & & \\
\hline 236.01 .01 & & & 129.60 & & \\
\hline & & & & & \\
\hline 236.01.02 & & & 139.96 & & \\
\hline & 2018 Yilı Kirs & Alacakları & & & \\
\hline 236.01 .02 & 2019 Yilı Kirc & Alacakları & 151.19 & & \\
\hline & 2020 Yilı Kir & Alacakları & & & \\
\hline 236.01 .02 & 2021 Yill Kirs & Alacakları & 163.29 & & \\
\hline 2 & 2022 Yilı Kirs & Alacakları & & & \\
\hline 483 & KAZANILM & MIŞ FAALIYET KİRALAMASI İSKONTO TUTARI HESABI & & & \\
\hline . & & & & 99.653 & \\
\hline 482.18 & 2018 Yilı ve S & nnrası İskonto Tutarı & 3.230 & & \\
\hline $\begin{array}{l}482.18 \\
482.19\end{array}$ & 2019 Yili ve $S$ & nnrası İskonto Tutarı & 10.815 & & \\
\hline 482.20 & 2020 Yili ve S & nrası İskonto Tutarı & 19.133 & & \\
\hline 482.21 & 2021 Yili ve S & nrası İskonto Tutarı & 28.251 & & \\
\hline 482.22 & 2022 Yilı ve S & nnrası İskonto Tutarı & 38.225 & & \\
\hline 102 & BANKA HES & ABI & & 30.000 & \\
\hline 102.01. & TL Mevduatı & & 30.000 & & \\
\hline & 237 & DÍĞER ÇEŞiTLİ ALACAKLAR SENETLERİ REESKONTU & & & \\
\hline & & HESABI (-) & & & 96.653 \\
\hline & & Faaliyet Kiralaması Sözleşmesine Dayalı Senetsiz Alacakların & & & \\
\hline & 237.05 & Reeskontu & & & \\
\hline & 237.05 .01 & & & & \\
\hline & 8 & & & & \\
\hline & 237.05 .01 & & & & \\
\hline & & & & & \\
\hline & 237.05.02 & & & & \\
\hline & & 2018 Y1lına Ait Reeskont Tutarı & 3.230 & & \\
\hline & 237.05 .02 & 2019 Yilına Ait Reeskont Tutarı & 10.815 & & \\
\hline & 1 & 2020 Yilına Ait Reeskont Tutarı & 19.133 & & \\
\hline & 237.05 .02 & 2021 Yilına Ait Reeskont Tutarı & 28.251 & & \\
\hline & 2 & 2022 Yilına Ait Reeskont Tutarı & 38.225 & & \\
\hline & & ALINAN DEPOZITO VE TEMINATLAR HESABI & & & 30.000 \\
\hline & 426.01 & Kozyatağ $\ldots .$. Ada,$\ldots$..Parsel 4. Nolu Dikkan & 30.000 & & \\
\hline & & FAALIYET KİRALAMASINDAN GELECEK YILLARA AİT & & & \\
\hline & 482 & GELİRLER HESABI & & & 704.061 \\
\hline & 480.02 & Yatırım Amaçlı Gayrimenkullerden & & & \\
\hline & 480.02 .01 & & 120.00 & & \\
\hline & 8 & & & & \\
\hline & 480.02 .01 & & 129.60 & & \\
\hline & 9 & & & & \\
\hline & 480.02 .02 & & 139.96 & & \\
\hline & 0 & 2018 Y1l Kira Gelirleri & & & \\
\hline & 480.02 .02 & 2019 Y1lı Kira Gelirleri & 151.19 & & \\
\hline & 1 & 2020 Y1lı Kira Gelirleri & & & \\
\hline & 480.02 .02 & 2021 Yılı Kira Gelirleri & 163.29 & & \\
\hline & 2 & 2022 Y1lı Kira Gelirleri & 6 & & \\
\hline & Kira Sözleşm & sinin Muhasebeleştirilmesi & & & \\
\hline
\end{tabular}




\begin{tabular}{|c|c|c|}
\hline 2 & & 01.01 .2018 \\
\hline 136 & \multicolumn{2}{|c|}{ DİĞER ÇEŞITLİ ALACAKLAR HESABI } \\
\hline 136.01 & \multicolumn{2}{|c|}{ Faaliyet Kiralaması Sözleşmesine Dayalı X Bankasından Diğer Çeşitli Alacaklar } \\
\hline 136.01.18 & \multicolumn{2}{|c|}{2018 Yılı Kira Alacakları } \\
\hline 237 & \multicolumn{2}{|c|}{ DİĞER ALACAK SENETLERİ REESKONTU HESABI (-) } \\
\hline 237.05 & \multicolumn{2}{|c|}{ Senetsiz Alacakların Reeskontu } \\
\hline 237.05.018 & \multicolumn{2}{|c|}{2018 Yılına Ait Reeskont Tutarı } \\
\hline 482 & \multicolumn{2}{|c|}{ FAALIYET İRALAMASINDAN GELECEK YILLARA AİT GELİRLER HESABI } \\
\hline 480.02 & \multicolumn{2}{|c|}{ Yatırım Amaçlı Gayrimenkullerden } \\
\hline 480.01.018 & \multicolumn{2}{|c|}{2018 Y1lı Kira Gelirleri } \\
\hline 382 & \multicolumn{2}{|c|}{ KAZANILMAMIŞ FAALIYET KIRALAMASI İSKONTO TUTARI HESABI (-) } \\
\hline \multirow[t]{12}{*}{382.18} & \multicolumn{2}{|c|}{2018 Yilı ve Sonrası İskonto Tutarı } \\
\hline & 236 & $\begin{array}{l}\text { DİĞER ÇEŞiTLI ALACAKLAR HESABI } \\
\text { Faaliyet Kiralaması Sözleşmesine Dayalı X Bankasından Diğer Çeşitli }\end{array}$ \\
\hline & 236.01 & Alacaklar \\
\hline & 236.01.18 & 2018 Yılı Kira Alacakları \\
\hline & 137 & DİĞER ALACAK SENETLERİ REESKONTU HESABI (-) \\
\hline & 137.05 & Faaliyet Kiralaması Sözleşmesine Dayalı Senetsiz Alacakların Reeskontu \\
\hline & 137.05 .018 & $\begin{array}{l}2018 \text { Yilına Ait Reeskont Tutar } \\
\text { FAALIYET KİRALAMASINDAN GELECEK AYLARA AİT }\end{array}$ \\
\hline & 382 & GELIRLER HESABI \\
\hline & 380.02 & Yatırım Amaçlı Gayrimenkullerden \\
\hline & 380.01 .018 & 2018 Yılı Kira Gelirleri \\
\hline & & $\begin{array}{l}\text { KAZANILMAMIŞ FAALIYYET KİRALAMASI İSKONTO TUTARI } \\
\text { HESABI (-) }\end{array}$ \\
\hline & 482.18 & 2018 Y1lı ve Sonrası İskonto Tutarı \\
\hline Dönemsellil & avramı Gereği I & nem Ayırıcı Hesapların İlgili Döneme Ait Yevmiye Kaydı \\
\hline
\end{tabular}

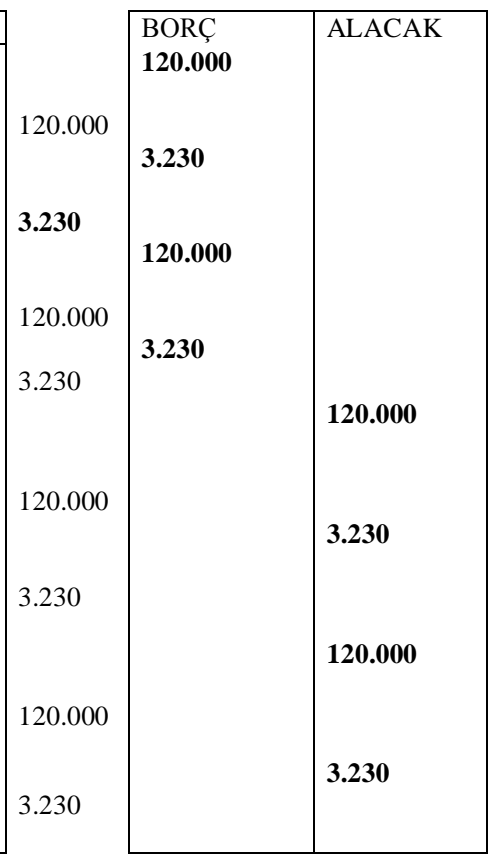

\begin{tabular}{|c|c|c|}
\hline 1 & & 01.01 .2018 \\
\hline 102 & \multicolumn{2}{|c|}{ BANKA HESABI } \\
\hline 102.01 & \multicolumn{2}{|c|}{ TL Mevduat } \\
\hline 137 & \multicolumn{2}{|c|}{ DİĞER ALACAK SENETLERİ REESKONTU HESABI (-) } \\
\hline 137.05 & \multicolumn{2}{|c|}{ Faaliyet Kiralaması Sözleşmesine Dayalı Senetsiz Alacakların Reeskontu } \\
\hline 382 & \multicolumn{2}{|c|}{ FAALIYET KİRALMASINDAN GELECEK AYLARA AITT GELİRLER HESABI } \\
\hline 380.02 & \multicolumn{2}{|c|}{ Yatırım Amaçlı Gayrimenkullerden } \\
\hline \multirow[t]{12}{*}{380.01 .018} & \multicolumn{2}{|c|}{2018 Yilı Kira Gelirleri } \\
\hline & \multirow[t]{2}{*}{136} & DİĞER ÇEŞITTLİ ALACAKLAR HESABI \\
\hline & & Faaliyet Kiralaması Sözleşmesine Dayalı X Bankasından Diğer Çeşitli \\
\hline & 136.01 & Alacaklar \\
\hline & 136.01.18 & 2018 Yı1ı Kira Alacakları \\
\hline & 604 & FAALIYET KİRALAMASINDAN GELİR VE KARLAR HES. \\
\hline & 649.01 & Kozyatağı .... Ada, ...Parsel 4. Nolu Dikkan Kira Geliri \\
\hline & 391 & HESAPLANAN KDV HESABI \\
\hline & 391.01 & Ocak 2018 Hesaplanan KDV \\
\hline & & KAZANILMAMIŞ FAALIYET KİRALAMASI İSKONTO TUTARI \\
\hline & 383 & HESABI (-) \\
\hline & 382.18 & 2018 Y1lı ve Sonrası İskonto Tutarı \\
\hline Ocak Ayına & t Kira Gelirinin & Yevmiye Kayd 1 \\
\hline
\end{tabular}

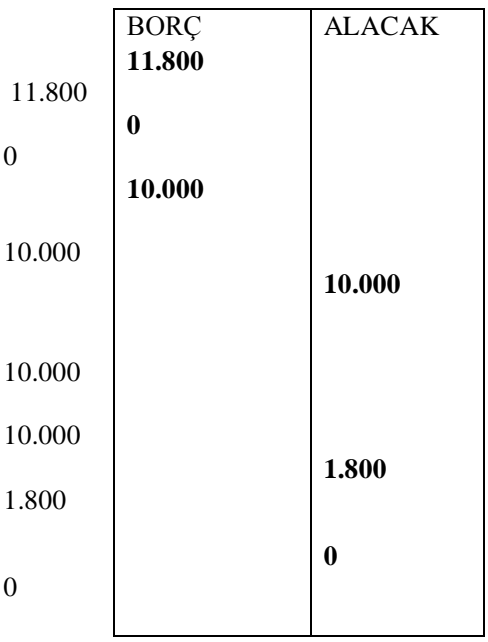

\begin{tabular}{|c|c|c|}
\hline 1 & & 01.02 .2018 \\
\hline 102 & \multicolumn{2}{|c|}{ BANKA HESABI } \\
\hline 102.01 & \multicolumn{2}{|c|}{ TL Mevduat } \\
\hline 137 & \multicolumn{2}{|c|}{ DİĞER ALACAK SENETLERİ REESKONTU HESABI (-) } \\
\hline 137.05 & \multicolumn{2}{|c|}{ Faaliyet Kiralaması Sözleșmesine Dayalı Senetsiz Alacakların Reeskontu } \\
\hline 382 & \multicolumn{2}{|c|}{ FAALIYET KİRALAMASINDAN GELECEK AYLARA AİT GELIRLER HESABI } \\
\hline 380.02 & \multicolumn{2}{|c|}{ Yatırım Amaçlı Gayrimenkullerden } \\
\hline \multirow[t]{11}{*}{380.01 .018} & \multicolumn{2}{|c|}{2018 Yilı Kira Gelirleri } \\
\hline & 136 & $\begin{array}{l}\text { DÍĞER CCEŞITLLI ALACAKLAR HESABI } \\
\text { Faaliyet Kiralaması Sözleşmesine Dayalı X Bankasından Diğer Çeşitli }\end{array}$ \\
\hline & 136.01 & Alacaklar \\
\hline & 136.01.18 & 2018 Yı1ı Kira Alacakları \\
\hline & 604 & FAALIYYT KİRALAMASINDAN GELİR VE KARLAR HES. \\
\hline & 604.01 . & Kozyatağı .... Ada, ...Parsel 4. Nolu Dikkan Kira Geliri \\
\hline & 391 & HESAPLANAN KDV HESABI \\
\hline & 391.01 & Şubat 2018 Hesaplanan KDV \\
\hline & & KAZANILMAMIŞ FAALIYET KİRALAMASI İSKONTO TUTARI \\
\hline & 383 & HESABI $(-)$ \\
\hline & 382.18 & 2018 Y1lı ve Sonrası İskonto Tutarı \\
\hline Ocak Ayına & Kira Geliriniı & Yevmiye Kayd 1 \\
\hline
\end{tabular}

\begin{tabular}{|l|l|l|}
\cline { 2 - 3 } 11.800 & \multicolumn{1}{|l|}{ BORÇ } & ALACAK \\
50 & $\mathbf{5 0}$ & \\
10.000 & $\mathbf{1 0 . 0 0 0}$ & \\
10.000 & & $\mathbf{1 0 . 0 0 0}$ \\
10.000 & & $\mathbf{1 . 8 0 0}$ \\
1.800 & & $\mathbf{5 0}$ \\
& & \\
& & \\
& & \\
& & \\
\end{tabular}


ÖRNEK VAKA 5; Çamlıca işletmesi 01.02.2014 tarihinde, X Vakfindan restorasyon veya onarım karşılı̆̆ uzun süreli faaliyet kiralaması kapsamında İstanbul ili, Kadıköy ilçesi, ... ada, ... parsel içerisinde yer alan toplam alanı 1.000 metrekare arsası üzerine 2.070 (414 metrekare x 5) metrekare toplam yapı alanına sahip 5 katlı kargir yapıyı 30 yıl süre ile kiralamıştır. Restorasyon ve onarım için gerekli faaliyet süresi 3 yıldır. Kullanma ve işletme hakk1 27 yıldır. Restorasyon ve onarım için tahmini muhammen bedel 2.484.000 TL'dir. Kesin teminat tutarı 74.520 TL'dir. İşletme restorasyon süresi içerisinde (3 Y1l) aylık sabit 3450 TL/ay ödeyecektir. İlk ay kirası sözleşme tarihinde ödenmiştir. 4. Yıldan (kullanma ve işletme süresi başlangıcından) itibaren aylık 10.800 TL/ay ödeyecektir. Takip eden yıllar bir önceki yılın TÜFE oranında artış yapılarak ödenecektir. Vakıf, katma değer vergisi ile gelir ve kurumlar vergisinden muaftır. İşletme faaliyet kiralaması kapsamında kiraladığ 5 katlı binayı yurt olarak kendisi kullanabileceği gibi, üçüncü şahıslara istediği bedelden faaliyet kiralaması yapabilme hakkına sahiptir.

Çamlıca işletmesi, 2014 yılı içerinde ilgili rölöve ve restitüsyon çalışmaları ile restorasyon projelerini tamamlamış ve ruhsat harçları ile beraber $272.000 \mathrm{TL}$ maliyete katlanmış ve $20.560 \mathrm{TL}$ indirilecek kdv doğmuştur. Ödemeler yıl sonunda yapılmıştır. 2015 yılında iskele ve kalıp işleri, cephe temizliği, kimyasal temizlik işleri, mikro kumlama işleri, enjeksiyon işleri yapılmış ve 344.000 TL maliyete katlanılmış ve 34.000 TL indirilecek kdv doğmuştur. Ödemeler yıl sonunda yapılmıştır. 2016 yılında ise taş işleri, mermer işleri, tuğla işleri, kiremit, sıva, derz, alçı, kartonpiyer, malakari, ahşap, çatı kargas, tavan döşeme, kündekari kapı ve kepenk ile doğrama işleri yapılarak restorasyon projesi tamamlanmıştır. 2016 yılında 950.000 TL maliyete katlanılmış ve 80.000 TL indirilecek KDV doğmuştur. Ödemeler 2016 yılında 3 ayda bir yapılmıştır.

- Çamlıca işletmesi gelecekle ilgili tüfe tahmini yapabilmek amacıyla son on yılın tüfe ortalamasını almış ve gelecekteki tüfe artış oranının yıllık \% 5 olacağını tahmin etmiştir. Karar alma tarihinde merkez bankası iç borçlanma faiz oranı $\% 6$ olup, risk primi olarak da \% 3,6 hesap ederek, ilgili projenin net bugünkü değerini hesaplarken iskonto oran1 yıllık nominal \%9,6, aylık nominal 0,096/12=0,008 olarak kabul etmiştir.

- $\quad$ İlgili projenin gerçeğe uygun değeri güvenilir olarak sürekli ölçülebilmektedir.

- $\quad$ Amortisman süresi olarak kullanma ve işletme hakk1 süresi olan 27 yıl kabul edilmiştir. Normal amortisman yöntemi uygulanmaktadır.

a) Çamlıca işletmesi, ilgili yapıyı yurt olarak işletmek amacıyla 15 Şubat 2017'de gerekli tefrişat ve teçhizat için $300.000 \mathrm{TL}+54.000 \mathrm{TL}$ KDV maliyete katlanmış ve bedelini peşin ödemiştir. İlgili tefrişat ve teçhizatın kullanım süresi 5 yıldır.

Çamlıca işletmesi 80 odalı (20 oda tek kişilik, 40 oda çift kişilik ve 20 oda 3 kişilik yatak kapasiteli) 160 kişi kapasitelidir. Yurtta kalan kişilerden tek kişilik oda için 750 TL/ay + \% $18 \mathrm{KDV}$, iki kişilik odalarda kişi başına $600 \mathrm{TL} / \mathrm{ay}$ + \% $18 \mathrm{KDV}, 3$ kişilik odalarda kişi başına $400 \mathrm{TL} /$ ay $+\% 18 \mathrm{KDV}$ ücret istemekte ve sözleşmeleri yıllık olarak yapmaktadır. Tahmini doluluk oranı merkezi bir konumda olması ve yakın çevresinde üniversite ve resmi kurumların çok olmasından dolayı beklenen tahmini doluluk oranı \% 95'dir. Beklenen tahsilat kaybı oranı da \% 2'dir. Aylık yaklaşık hasılatın \% 38 oranında hizmet maliyetine katlanılması söz konusu olacaktır. Kurumlar vergisi oranı \% 20'dir. Yıllık TÜFE Artış Beklentisi \% 5' 
03 Şubat 2017'de Çamlıca işletmesi ilgili yapıyı tamamladıktan sonra tefrişat ve teçhizat maliyetine katlanmadan önce yurt olarak işletmek yerine, mevcut hali ile kira sözleşmesini bütünüyle devretmek istediği takdirde 4.500.000 TL bir bedelle teklif bulmuştur.

Çamlıca işletmesi, sahip olduğu intifa (kullanma) hakkının gerçeğe uygun değerini güvenilir olarak ölçebilmektedir ve binadaki kira hakkını yatırım amaçlı bir gayrimenkul kalemi (zorunlu tutulmamasına rağmen) olarak sınıflandırmaktadır. İntifa hakkının gerçeğe uygun değerini ise; kargir yapının restorasyon ve onarım için yapmış olduğu maliyet tutarlarının (ödeme tarihleri esas alınarak) ile restorasyon süreci (3 Y1l) boyunca ve kullanma ve işletme hakkı (27 yıl) yapacağı kira ödemelerinin bugünkü değeridir.

Çamlıca işletmesi dönemsellik kavramı gereği dönem ayrıştırıcı hesapları kullanırken alacak, borç ve gelirlerini yevmiye kayıt tarihi itibariyle gerçeğe uygun değerlerini dikkate alarak yevmiye kayıtlarını yapmamaktadır.

\begin{tabular}{|l|l|l|l|l|l|c|}
\hline Aylar & $1-11$ & 12 & 24 & 25 & 36 & Toplam \\
\hline İlk Üç Yıl Kira Ödemeleri & 3.450 & 3.450 & 3.450 & 3.450 & 3.450 & $\mathbf{1 2 4 . 2 0 0}$ \\
\hline $\begin{array}{l}\text { Restorasyon Harcamaları (Ödeme } \\
\text { Tarihi itibariyle) }\end{array}$ & & 272.000 & 344.000 & & 950.000 & 1.566 .000 \\
\hline Toplam Nominal Tutar & 3.450 & 275.450 & 347.450 & 3.450 & 953.450 & $\mathbf{1 . 6 9 0 . 2 0 0}$ \\
\hline İskonto Oranı & 0 & 1 & 1 & 1 & 1 & \\
\hline Payda & 1 & 1 & 1 & 1 & 1 & \\
\hline $\begin{array}{l}\text { Restorasyon Sürecindeki Nakit } \\
\text { Çısıslarını Bugünkü Değeri }\end{array}$ & 3.450 & 235.512 & 269.983 & 2.660 & 170.155 & $\mathbf{1 . 2 9 6 . 8 8 8}$ \\
\hline
\end{tabular}

\begin{tabular}{|c|c|c|c|c|c|c|}
\hline & 1 & 12 & 24 & 25 & 36 & \\
\hline İlk Üç Y1l Kira Ödemeleri & 10.800 & 10.800 & 11.340 & 11.907 & 11.907 & 408.564 \\
\hline İskonto Oranı & 1,43 & 1,56 & 1,71 & 1,73 & 1,89 & \\
\hline \multirow[t]{2}{*}{ Kira Ödemelerinin Bugünkü Değeri } & 7.566 & 6.931 & 6.614 & 6.890 & 6.312 & 249.055 \\
\hline & 1 & 12 & 24 & 25 & 36 & \\
\hline İkinci Üç Yı1 Kira Ödemeleri & 12.502 & 12.502 & 13.127 & 13.783 & 13.784 & 472.956 \\
\hline İskonto Oranı & 1,90 & 2,08 & 2,28 & 2,30 & 2,51 & \\
\hline \multirow[t]{2}{*}{ Kira Ödemelerinin Bugünkü Değeri } & 6.575 & 6.023 & 5.747 & 5.987 & 5.484 & 216.410 \\
\hline & 1 & 12 & 24 & 25 & 36 & \\
\hline Üçüncü Üç Yıl Kira Ödemeleri & 14.473 & 14.473 & 15.197 & 15.957 & 15.958 & 547.535 \\
\hline İskonto Oranı & 2,53 & 2,77 & 3,04 & 3,07 & 3,35 & \\
\hline \multirow[t]{2}{*}{ Kira Ödemelerinin Bugünkü Değeri } & 5.713 & 5.233 & 4.994 & 5.202 & 4.766 & 188.056 \\
\hline & 1 & 12 & 24 & 25 & 36 & \\
\hline Dördüncü Üç Yıl Kira Ödemeleri & 16.756 & 16.756 & 17.594 & 18.474 & 18.474 & 633.887 \\
\hline İskonto Oranı & 3,38 & 3,68 & 4,05 & 4,09 & 4,46 & \\
\hline \multirow[t]{2}{*}{ Kira Ödemelerinin Bugünkü Değeri } & 4.965 & 4.548 & 4.340 & 4.521 & 4.142 & 163.422 \\
\hline & 1 & 12 & 24 & 25 & 36 & \\
\hline 5.Üç Yıl Kira Ödemeleri & 19.398 & 19.298 & 20.263 & 21.276 & 21.277 & 730.155 \\
\hline İskonto Oranı & 4,50 & 4,91 & 5,40 & 5,44 & 5,94 & \\
\hline \multirow[t]{2}{*}{ Kira Ödemelerinin Bugünkü Değeri } & 4.314 & 3.932 & 3.752 & 3.908 & 3.580 & 141.300 \\
\hline & 1 & 12 & 24 & 25 & 36 & \\
\hline 6.Üç Yıl Kira Ödemeleri & 22.341 & 22.341 & 23.259 & 24.422 & 24.422 & 840.463 \\
\hline İskonto Oranı & 5,99 & 6,54 & 7,19 & 7,25 & 7,92 & \\
\hline \multirow[t]{2}{*}{ Kira Ödemelerinin Bugünkü Değeri } & 3.730 & 3.417 & 3.233 & 3.367 & 3.085 & 122.118 \\
\hline & 1 & 12 & 24 & 25 & 36 & \\
\hline 7.Üç Yıl Kira Ödemeleri & 25.643 & 25.644 & 26.926 & 28.272 & 28.272 & 970.104 \\
\hline İskonto Oranı & 7,98 & 8,71 & 9,59 & 9,66 & 10,55 & \\
\hline \multirow[t]{2}{*}{ Kira Ödemelerinin Bugünkü Değeri } & 3.213 & 2.944 & 2.809 & 2.926 & 2.681 & 105.774 \\
\hline & 1 & 12 & 24 & 25 & 36 & \\
\hline 8.Üç Yil Kira Ödemeleri & 29.686 & 29.686 & 31.170 & 32.729 & 32.729 & 1.123 .019 \\
\hline İskonto Oranı & 10,63 & 11,61 & 12,77 & 12,87 & 14,05 & \\
\hline
\end{tabular}




\begin{tabular}{|c|c|c|c|c|c|c|}
\hline Kira Ödemelerinin Bugünkü Değeri & 2.792 & 2.558 & 2.441 & 2.543 & 2.329 & 91.911 \\
\hline & 1 & 12 & 24 & 25 & 36 & \\
\hline 9.Üç Yıl Kira Ödemeleri & 34.365 & 34.366 & 36.085 & 37.889 & 37.890 & 1.300 .090 \\
\hline İskonto Oranı & 14,16 & 15,46 & 17,01 & 17,15 & 18,72 & \\
\hline Kira Ödemelerinin Bugünkü Değeri & 2.426 & 2.223 & 2.121 & 2.209 & 2.024 & 79.868 \\
\hline $\begin{array}{l}\text { Kullanma ve İssletme Sürecinde Nakit } \\
\text { Çıkışlarının Nominal Değeri (Toplam) }\end{array}$ & & & & & & 7.026 .773 \\
\hline $\begin{array}{l}\text { Kullanma ve İssletme Sürecinde Nakit } \\
\text { Çıışslarının Bugünkü Değeri (Toplam) }\end{array}$ & & & & & & 1.357.914 \\
\hline $\begin{array}{l}\text { Nakit Çıkışlarının Bugünkü değeri } \\
\text { Intifa Hakkının Değeri ( Toplam) }\end{array}$ & & 1.296 .888 & + & 1.357.914 & & 2.654.803 \\
\hline
\end{tabular}

\begin{tabular}{|c|c|c|c|}
\hline Aylık Potansiyel Brüt Gelir & $=(20 * 750)+(80 * 600)+(60 * 400)$ & $=$ & 87.000 \\
\hline -Boşluk Kaybl & $=87.000 * 0,05$ & $=$ & -4.350 \\
\hline -Tahsilat Kaybl & $=(87000-4350) * 0,02$ & $=$ & -1.653 \\
\hline Efektif Brüt Gelir & & $=$ & 80.997 \\
\hline - Işsletme Gideri (Hizmet Maliyeti) & $=87.000 * 0,38$ & $=$ & -33.060 \\
\hline Vergiden Önceki İşletme Geliri & & $=$ & 47.947 \\
\hline Vergi & $=47.947 * 0,20$ & $=$ & -9.588 \\
\hline Vergiden Sonraki Net İsletme Geliri & $(A y l l k)$ & $=$ & 38.349 \\
\hline Vergiden Sonraki Net İşletme Geliri & (Ylllik) 38349TL/Ay *12Ay & $=$ & 460.188 \\
\hline
\end{tabular}

\begin{tabular}{|c|c|c|c|c|c|c|c|c|c|c|}
\hline Yillar & 1 & 2 & 9 & 10 & 16 & 17 & 25 & 27 & 27 & Toplam \\
\hline $\begin{array}{l}\text { Nakit } \\
\text { Girişlerinin } \\
\text { Nominal Tutarı }\end{array}$ & 460188 & $\begin{array}{l}483197, \\
4\end{array}$ & 679907,3 & 713902,6 & 956697,8 & 1004533 & 1484152 & 1558360 & 1636278 & 25.158.076 \\
\hline İskonto Oranı & 1,096 & 1,201 & 2,282 & 2,501 & 4,335 & 4,751 & 9,892 & 10,841 & 11,882 & \\
\hline $\begin{array}{l}\text { Nakit } \\
\text { Girişlerinin } \\
\text { Bugünkü Değeri }\end{array}$ & $\begin{array}{l}419879, \\
6\end{array}$ & $\begin{array}{l}402256, \\
9\end{array}$ & 297957,8 & 285452,2 & 220701,8 & 211438,8 & 150042,6 & 143745,2 & 137712,1 & 6.860 .659 \\
\hline
\end{tabular}

\begin{tabular}{|llll|}
\hline Nakit Girişlerinin Bugünkü Değeri & & $=$ & 6.860 .659 \\
Nakit Çıkş̧larının Net Bugünkü Değeri & $(-)$ & $=$ & -2.654 .803 \\
& & & \\
Projenin Net Bugünkü Değeri & $=$ & $\mathbf{4 . 2 0 5 . 8 5 6}$ \\
\hline
\end{tabular}

Projenin net bugünkü değeri pozitif bir değer olduğu için Çamlıca işletmesi yatırım kararını almıştır. (Tefrişat ve teçhizat maliyetine katlanmadan önce). gibidir.

Çamlıca İşletmesinin Sözleşme tarihinde yapması gereken yevmiye kaydı aşağıdaki

\begin{tabular}{|c|c|c|c|c|}
\hline 1 & 1.2 .2014 & & BORÇ & ALACAK \\
\hline $\begin{array}{l}\mathbf{9 0 1} \\
901.01 \\
901.01 .001 \\
901.01 .002 \\
901.01 .003 \\
\\
\\
\\
\\
\text { Restorasyon } \\
\text { Muhasebele }\end{array}$ & 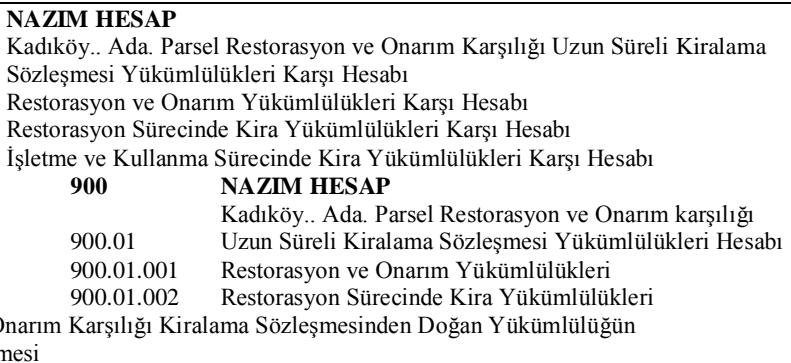 & $\begin{array}{l}\mathbf{9 . 6 3 4 . 9 7 3} \\
2.484 .000 \\
124.200 \\
7.026 .773\end{array}$ & 9.634 .973 & 9.634 .973 \\
\hline
\end{tabular}




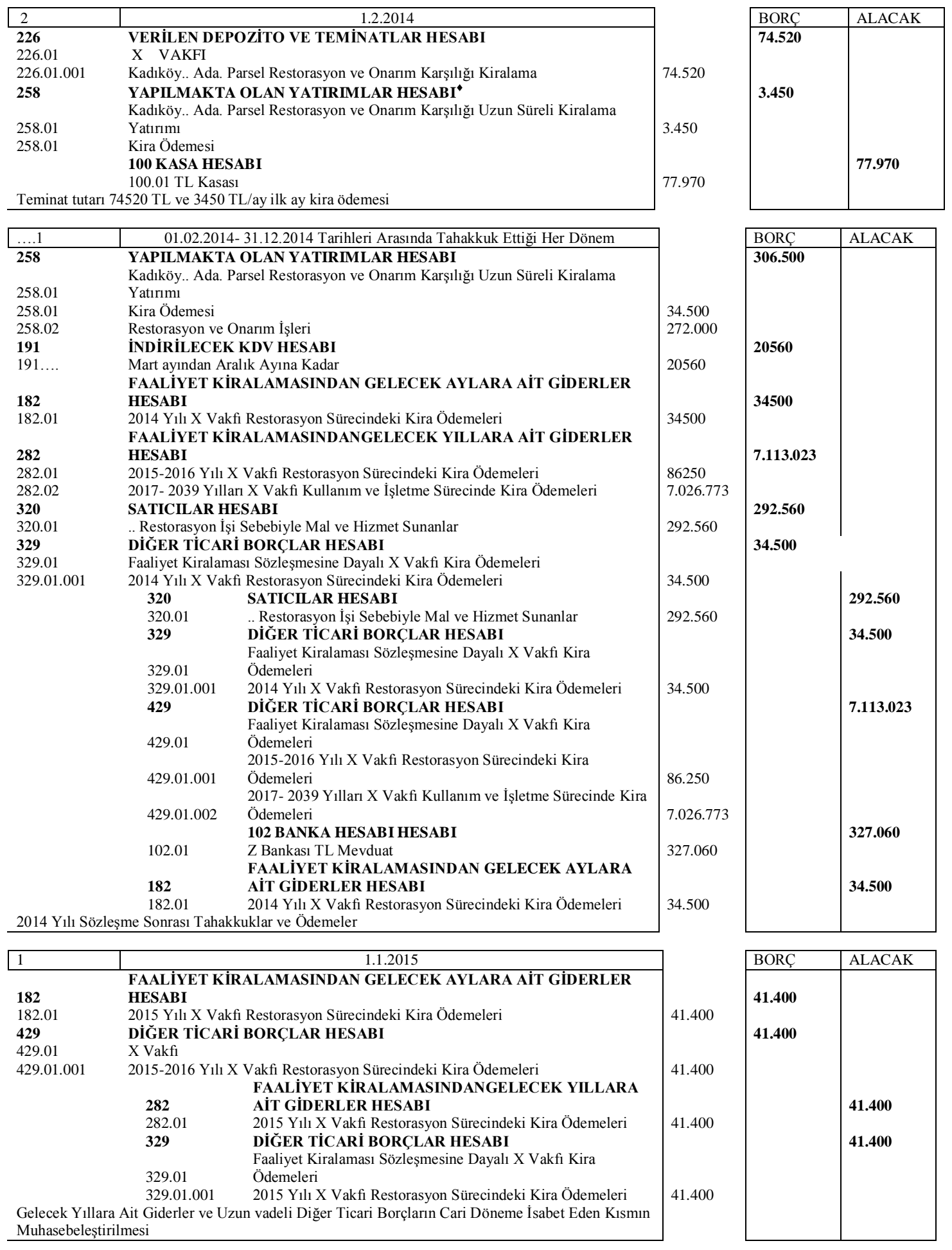

- TFRS 16 madde 24 d bendi uyarınca faaliyet kiralamasına ilişkin maliyetler ilgili hesapta toplanmıştır. Kiralama sözleşmesi kiralayana hem kullanma hem de kiralık gayrimenkulden bir başka faaliyet kiralaması yoluyla gelir elde etme imkanı sunmaktadır. Gelir elde etme imkanı sunması nedeniyle katlanılan maliyetler sözleşmeye konu varlığın kullanım zamanına kadar yapılmakta olan yatırımlar hesabında takip edilmelidir. Faaliyet kiralaması bir hizmet alımı ve hizmet sunumu demektir. Depolanabilme özelliği söz konusu değildir. Mülkiyet hakkı doğurmaz alım satıma konu değildir. Eğer sözleşmede yer alıyorsa hakkın devri söz konusu olabilir. İlgili hakkın devir olma zamanına kadar, hakkın piyasa değeri ile maliyet değeri arasındaki fark özkaynaklarda sermaye yedeği içerisinde 525 yatırım amaçlı gayrimenkuller değer artış hesabında takip edilmelidir. İlgili değer artışı tutarı üzerinden amortisman ayrılmamalıdır. 


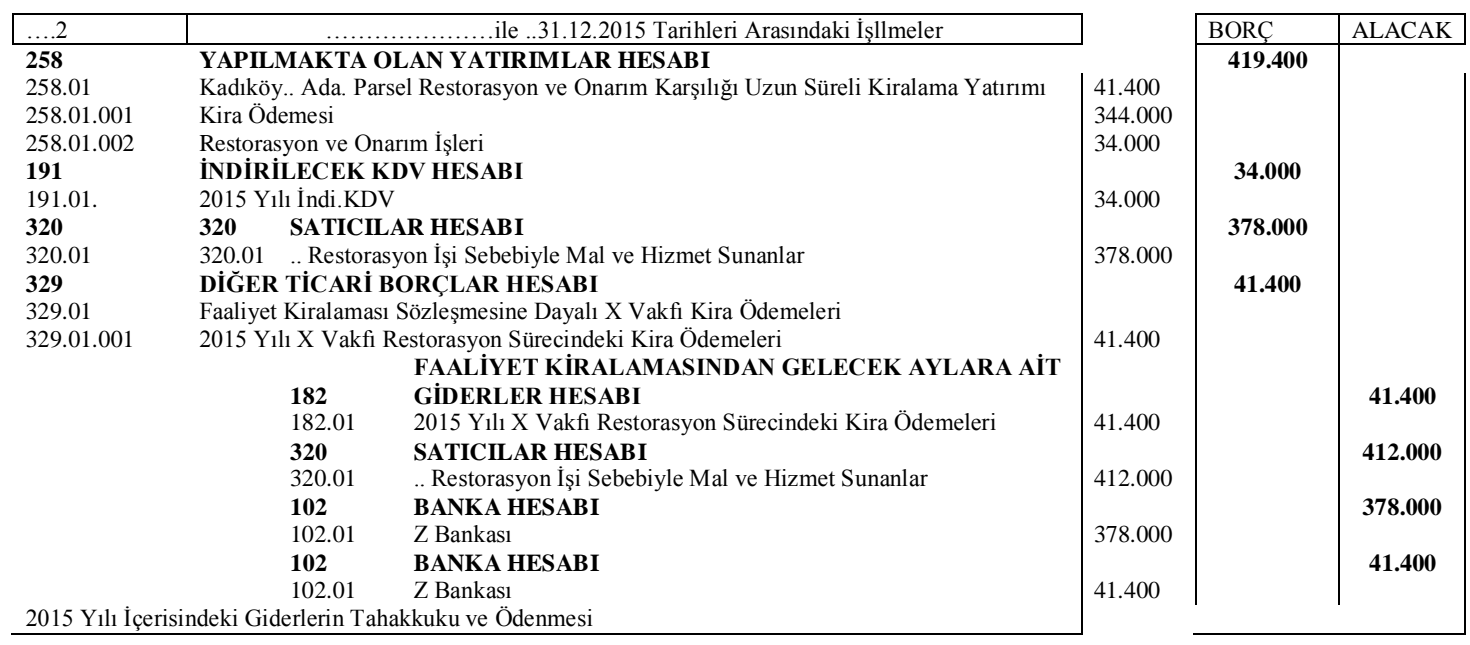

\begin{tabular}{|c|c|c|}
\hline$\ldots .1$ & & 1.1.2016 \\
\hline & \multicolumn{2}{|c|}{ FAALIYET KİRALAMASINDAN GELECEK AYLARA AİT GİDERLER } \\
\hline 182.01 & HESABI & 2015 Yılı X Vakfi Restreasyon Sürecindeki Kira Ödemeleri \\
\hline 429 & \multicolumn{2}{|c|}{ DİĞER TICCARİ BORÇLAR HESABI } \\
\hline 429.01 & \multicolumn{2}{|c|}{ Faaliyet Kiralaması Sözleşmesine Dayalı X Vakfı Kira Ödemeleri } \\
\hline \multirow[t]{7}{*}{429.01 .001} & \multicolumn{2}{|c|}{ 2015-2016 Yılı X Vakfi Restreasyon Sürecindeki Kira Ödemeleri } \\
\hline & & FAALIYET KİRALAMASINDAN GELECEK YILLARA AITT \\
\hline & 282 & GIDERLER HESABI \\
\hline & 282.01 & 2015 Y $11_{1}$ X Vakfi Restorasyon Sürecindeki Kira Ödemeleri \\
\hline & & DİĞER TİCARİ BORÇLAR HESABI \\
\hline & 329.01 & Faaliyet Kiralaması Sözleşmesine Dayalı X Vakfı Kira Ödemeleri \\
\hline & 329.01.001 & 2016 Y1lı X Vakfi Restorasyon Sürecindeki Kira Ödemeleri \\
\hline \multicolumn{3}{|c|}{$\begin{array}{l}\text { Gelecek Yıllara Ait Giderler ve Uzun vadeli Diğer Ticari Borçların Cari Döneme İsabet Eden Kısmın } \\
\text { Muhasebeleștirilmesi }\end{array}$} \\
\hline
\end{tabular}

\begin{tabular}{|l|l|l|}
\cline { 2 - 3 } 4 & BORÇ & ALACAK \\
\cline { 2 - 3 } 41.400 & $\mathbf{4 1 . 4 0 0}$ & \\
41.400 & $\mathbf{4 1 . 4 0 0}$ & \\
41.400 & & $\mathbf{4 1 . 4 0 0}$ \\
41.400 & & $\mathbf{4 1 . 4 0 0}$ \\
& & \\
& & \\
\hline
\end{tabular}

\begin{tabular}{|c|c|c|}
\hline$\ldots .2$ & \multicolumn{2}{|c|}{..................ile ..31.12.2016 Tarihleri Arasındaki İşlemler } \\
\hline 258 & \multicolumn{2}{|c|}{ YAPILMAKTA OLAN YATIRIMLAR HESABI } \\
\hline & \multicolumn{2}{|c|}{ Kadıköy.. Ada. Parsel Restorasyon ve Onarım Karşılığı Uzun Süreli Kiralama } \\
\hline 258.01 & \multicolumn{2}{|l|}{ Yatırımı } \\
\hline 258.01 .001 & \multicolumn{2}{|l|}{ Kira Ödemesi } \\
\hline 258.01 .002 & \multicolumn{2}{|c|}{ Restorasyon ve Onarım İșleri } \\
\hline 191 & \multicolumn{2}{|c|}{ İNDİRILECEK KDV HESABI } \\
\hline 320 & \multicolumn{2}{|c|}{ SATICILAR HESABI } \\
\hline 320.01 & \multicolumn{2}{|c|}{320.01 .. Restorasyon İşi Sebebiyle Mal ve Hizmet Sunanlar } \\
\hline 329 & \multicolumn{2}{|c|}{ DİĞER TİCARİ BORÇLAR HESABI } \\
\hline 329.01 & \multicolumn{2}{|c|}{ Faaliyet Kiralaması Sözleşmesine Dayalı X Vakfı Kira Ödemeleri } \\
\hline \multirow[t]{10}{*}{329.01 .001} & \multicolumn{2}{|c|}{2016 Yılı X Vakfi Restreasyon Sürecindeki Kira Ödemeleri } \\
\hline & & FAALIYET KIRALAMASINDAN GELECEK AYLARA \\
\hline & & AITT GIDERLER HESABI \\
\hline & 182.01 & 2015 Yılı X Vakfi Restreasyon Sürecindeki Kira Ödemeleri \\
\hline & & SATICILAR HESABI \\
\hline & 320.01 & .. Restorasyon İşi Sebebiyle Mal ve Hizmet Sunanlar \\
\hline & 102 & BANKA HESABI \\
\hline & 102.01 & Z Bankası \\
\hline & 102 & BANKA HESABI \\
\hline & 102.01 & Z Bankası \\
\hline 2016 Yili İç & deki Giderlerin Tah & kuku ve Ödenmesi \\
\hline
\end{tabular}

\begin{tabular}{|l|c|c|}
\cline { 2 - 3 } & BORÇ & ALACAK \\
\cline { 2 - 3 } 41.400 & $\mathbf{9 9 1 . 4 0 0}$ & \\
950.000 & & \\
& $\mathbf{8 0 . 0 0 0}$ & \\
1.030 .000 & $\mathbf{1 . 0 3 0 . 0 0 0}$ & \\
& $\mathbf{4 1 . 4 0 0}$ & \\
41.400 & & \\
41.400 & & $\mathbf{4 1 . 4 0 0}$ \\
1.030 .000 & & $\mathbf{1 . 0 3 0 . 0 0 0}$ \\
1.030 .000 & & $\mathbf{1 . 0 3 0 . 0 0 0}$ \\
41.400 & & $\mathbf{4 1 . 4 0 0}$ \\
\hline
\end{tabular}




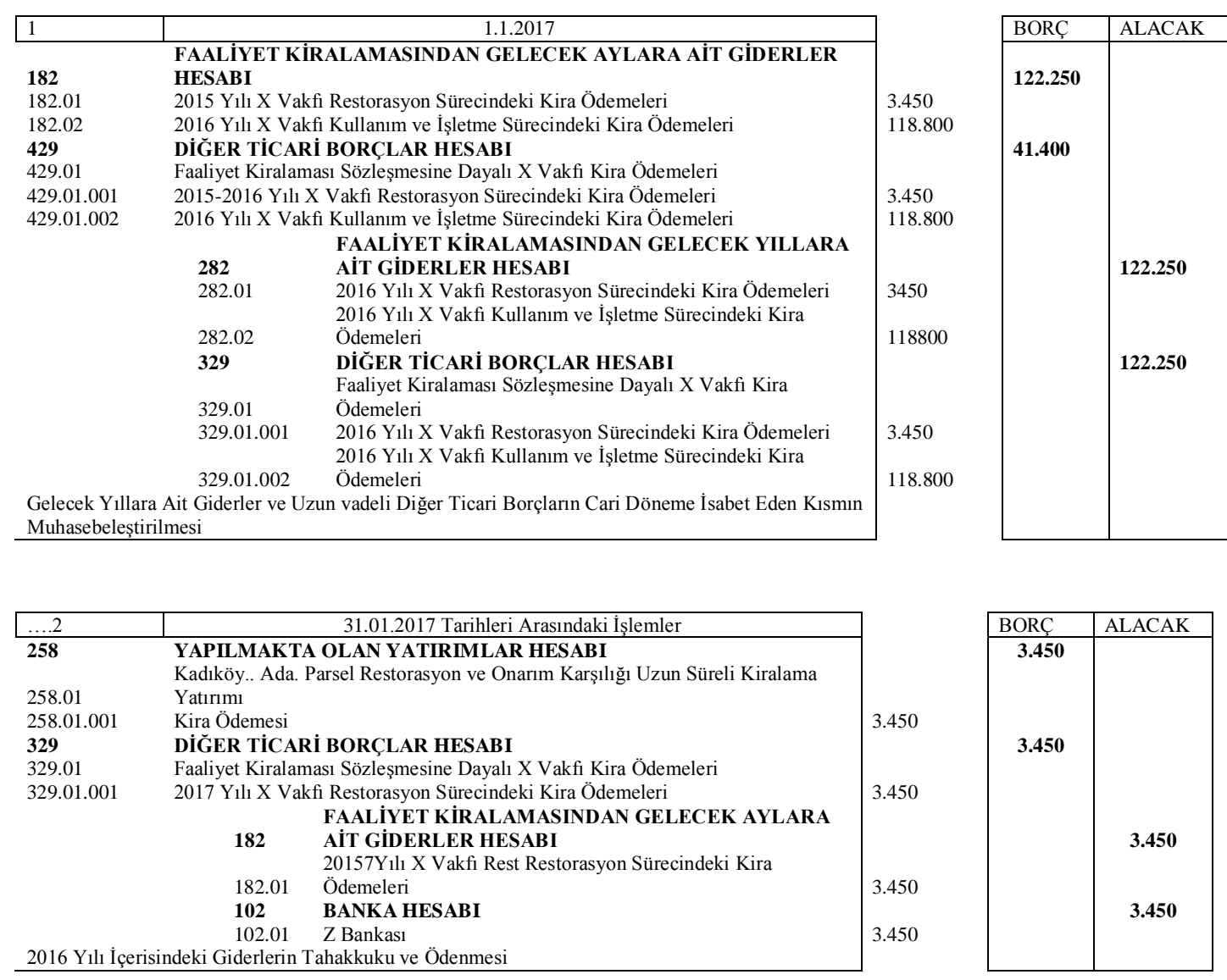

258 YAPILMAKTA OLAN YATIRIMLAR HESABI

258.01 Kadıköy.. Ada. Parsel Restorasyon ve Onarım

Karşılığı Uzun Süreli Kiralama Yatırımı

253.01.001 Kira Ödemesi

253.01.002 Restorasyon ve Onarım İşleri

\begin{tabular}{lc|l} 
Borç & \multicolumn{1}{l}{ Alacak } \\
\hline 01.02 .2014 & 3.450 & \\
$\ldots . / \ldots / .2014$ & 306.500 & \\
$\ldots . / \ldots . / 2015$ & 419.400 & \\
$. . / \ldots / 2016$ & 991.400 & \\
31.01 .2017 & 3.450 & \\
Toplam & $\mathbf{1 . 7 2 4 . 2 0 0}$ &
\end{tabular}

İşletme 2.484.000 TL muhammen bedelli, $(36 * 3450)=124.200 \mathrm{TL}$ restorasyon sürecindeki kira ödemeleri yükümlülüğ̈̈ 1.724 .000 TL'ye tamamlanmıştır. Vakıf incelmesinden de kesin onay 02.02.2017 tarihinde alınmıştır. İlgili tarih itibariyle ilgili proje yatırım amaçlı gayrimenkul olarak sınıflandırılmıştır. 


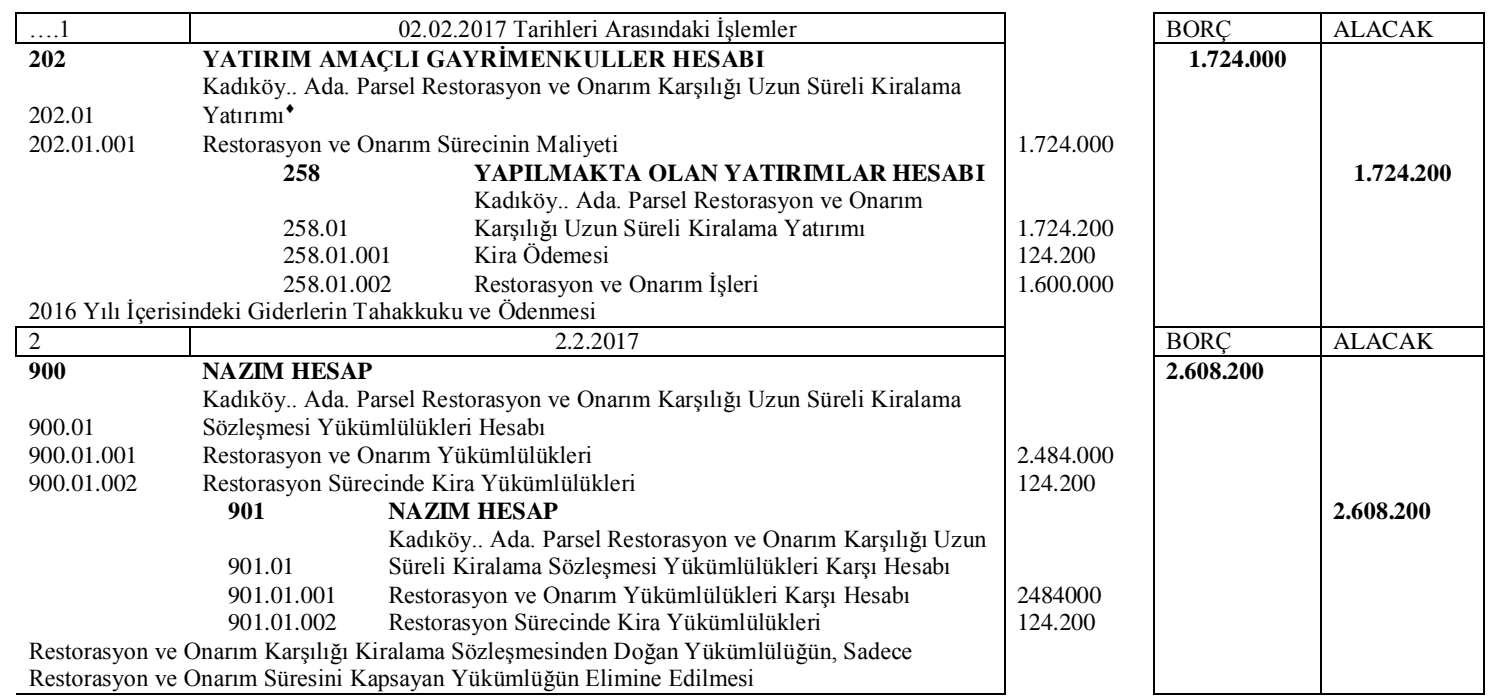

Nazım Hesapta takip etmiş olduğumuz yükümlülüklerimizin mahsubu kesin onayın beklenmesi sebebiyle ödeme tarihlerinde değil kesin onay tarihinde 02.02.2017 tarihinde yapılmıştır.

\section{Teklifin Değerlendirilmesi;}

Varlığın Gerçeğe Uygun Değeri (Piyasa Teklifi) $\quad=4.500 .000 \mathrm{TL}$

Yapılan Yatırım Tutarı $\quad=-1.724 .000 \mathrm{TL}$

Değerleme Farkı (iNTIFA HAKKI BEDELI) $\quad=2.776 .000 \mathrm{TL}$

Restorasyon ve onarım karşılığı kiralama sözleşmesinden kaynaklanan hakkın devir edilmesinden elde edilebilecek kazancin 2.776.000 TL'nin, projenin net bugünkü değerinden 4.205.856 düşük olduğu için işletme devir işleminden vazgeçmiştir. Fakat varlığa ilişkin intifa hakkının mali tablolarda gereceğe uygun değeri yansıtması ve ihtiyatlılık kavramı gereği 2.776.000 TL'yi intifa hakkı bedeli olarak kayıtlarına almıştır. İntifa hakkı için itfa payı ayrılmayacaktır. Her yıl hakkın devir bedeline ilişkin gerçeğe uygun değer araştırması yapılacak ve artış veya azalışlar ilgili intifa hakkı bedeli hesabı kullanılarak raporlama tarihindeki değeri doğru ve gerçek olarak ifade edilecektir. 525 Yatırım amaçlı gayrimenkuller değer artışı hesabı da kapsamlı gelir tablosun da raporlanacaktır.

\begin{tabular}{|c|c|c|c|c|}
\hline 3 & 03.02.2017 Tarihleri Arasındaki İșlemler & \multirow[b]{5}{*}{2.776 .000} & BORÇ & ALACAK \\
\hline 202 & $\begin{array}{l}\text { YATIRIM AMAÇLI GAYRİMENKULLER } \\
\text { Kadıköy.. Ada. Parsel Restorasyon ve Onarım Karş1lığı Uzun Süreli Kiralama }\end{array}$ & & \multirow[t]{4}{*}{2.776 .000} & \multirow[b]{4}{*}{ 2.776.000 } \\
\hline 202.01 & Yatırımı & & & \\
\hline 258.01.003 & İntifa Hakkı Bedeli & & & \\
\hline 2017 Y1lı İç & $\begin{array}{cl}525 & \text { YATIRIM AMAÇLI GAYRIMENKULLER DEĞER ARTIŞI } \\
& \text { Kadıköy.. Ada. Parsel Restorasyon ve Onarım Karşılığı Uzun Süreli } \\
525.01 & \text { Kiralama Yatırımı } \\
525.01 .01 & \text { İntifa Hakk1 Değer Artışı } \\
\text { ade İntifa Hakkının Muhasebeleştirilmesi }\end{array}$ & & & \\
\hline
\end{tabular}

\footnotetext{
• TFRS 16 madde 96 ve madde 79 doğrultusunda “yatırım amaçlı gayrimenkuller hesabı" kapsamına alınmıştır.
} 


\begin{tabular}{|c|c|c|c|c|}
\hline 4 & 15.02.2017 Tarihleri Arasındaki İșlemler & & BORÇ & ALACAK \\
\hline 202 & YATIRIM AMAÇLI GAYRİMENKULLER & & 300.000 & \\
\hline & Kadıköy.. Ada. Parsel Restorasyon ve Onarım Karș1lığı Uzun Süreli Kiralama & & & \\
\hline 202.01 & Yatırımı & & & \\
\hline 258.01.004 & Tefrişat ve Techizat Bedeli & 300.000 & & \\
\hline 191 & İNDİRILECEK KDV & & 54.000 & \\
\hline 191.02 & Şubat KDV & 54.000 & & \\
\hline & BANKA & & & 354.000 \\
\hline & V Bankası & 354.000 & & \\
\hline \multicolumn{2}{|c|}{2017 Y11 İçerisinde Tefrișat ve Techizat Maliyetlerinin Muhasebeleștirilmesi } & & & \\
\hline
\end{tabular}

202 YATIRIM AMAÇLI GAYRIMENKULLER HESABI

202.01 Kadıköy.. Ada. Parsel Restorasyon ve Onarım Karşılığı Uzun Süreli

Faaliyet Kiralaması Yatırımı

202.01.001 Kira Ödemesi

202.01.002 Restorasyon ve Onarım İşleri

202.01.003 İntifa Hakkı Bedeli

Borç 202.01.04 Tefrişat ve Techizat Bedeli

01.02 .2014

.........2014

.../.../2015

../.../2016

31.01.2017

Toplam 1

03.02.2017 İntifa hakkı Bedeli

Toplam 2

15.02.2017 Tefrişat ve Techizat

Toplam 3

3.450
306.500
419.400
991.400
3.450
$\mathbf{1 . 7 2 4 . 2 0 0}$
2.776 .000
$\mathbf{4 . 5 0 0 . 2 0 0}$
300.000
$\mathbf{4 . 8 0 0 . 2 0 0}$

Çamlıca işletmesi, 1.724.200 TL'yi kiralama sözleşmesi süresi içinde (27 y1l), 300.000 TL'yi 5 yıl içinde amortisman tutarını hesaplayarak, hizmet üretim maliyeti hesabı aracılığıyla gelir tablosu ile ilişkilendirecektir. 2.776.000 TL tutarındaki intifa hakkı için itfa payı hesaplamayacaktır. Yurt olarak işletmeden kaynaklanan gelirlerini de hasılat standardı doğrultusunda muhasebeleştirecektir.

Çamlıca işletmesi sözleşmeden doğan hakkını, gerçeğe uygun değerinin güvenilir olarak ölçülebilmesine rağmen, yatırım amaçlı gayrimenkul olarak sınıflandırmayı seçmemiş olsaydı (çünkü zorunluluk yok) sadece 1.724.200 TL $+300.000 \mathrm{TL}=2.024 .200 \mathrm{TL}$ tutarı maddi olmayan duran varlıklar grubunda yer alan özel maliyet hesabında takip edecek, 1.724.000 TL tutarı kiralama süresinde içerinde, 300.000 TL'yi 5 yıl içinde itfa edecek ve birikmiş itfa payları hesabını kullanacaktı. Sözleşmeden doğan hakkın doğru ve gerçek bedelinin mali tablolarda görülmesi mümkün olmayacaktır. Çamlıca işletmesi sözleşmeden doğan hakkını, gerçeğe uygun değerinin güvenilir olarak ölçemediği durumlarda istese de yatırım amaçlı gayrimenkul olarak sinıflandırmayı seçemeyecektir. Bu durumda mecburen, 1.724.200 TL + 300.000 TL = 2.024.200 TL tutarı maddi olmayan duran varlıklar grubunda yer alan özel maliyet hesabında takip edecek, 1.724.000 TL tutarı kiralama süresinde içerinde 300.000 TL'yi 5 yıl içinde itfa edecek ve birikmiş itfa payları hesabını kullanacaktı. 1.724.000 TL'yi vergi avantajından faydalanmak için 5 yılda itfa etmiş olursa eğer, ertelenmiş vergi yükümlülüğü doğacak ve muhasebeleştirmesini yapmalidır.

b) Çamlıca işletmesi, ilgili yapıyı yurt olarak işletmek amacıyla kiralamış olmasına rağmen kararından vazgeçmiş ve butik otel olarak kullanılması için aylık 38.000TL $+\mathrm{KDV}$ bedelle, otel için gerekli olan tefrişat ve teçhizat maliyetine katlanmadan Kartal işletmesine faaliyet kiralaması kapsamında 27 yıllığına 03.Şubat 2017'de kiraya vermiştir. 
Takip eden yıllar bir önceki yılın TÜFE oranında artış yapılarak tahsil edilecektir. Çamlıca işletmesi dönemsellik kavramı gereği dönem ayrıştırıcı hesapları kullanırken alacak, borç ve gelirlerini yevmiye kayıt tarihi itibariyle gerçeğe uygun değerlerini dikkate alarak yevmiye kayıtlarını yapmaktadır. 31.12.2017 tarihinde Çamlıca işletmesi yatırım amaçlı gayrimenkul için amortisman tutarını muhasebeleştirmiştir. Yatırım amaçlı gayrimenkulün ekonomik ömrü kalan kira süre kadardır. Azalan bakiyeler yöntemine göre amortisman tutarını hesaplamakta ve endirekt kayıt yöntemine göre kayıt etmektedir. Yatırım amaçlı gayrimenkulün kalıntı değeri olarak 24.200 TL olarak varsayımını dikkate almıştır. İntifa hakkı bedeline amortisman ayrılmamaktadır.

\begin{tabular}{|c|c|c|c|c|c|c|c|c|}
\hline \multicolumn{9}{|c|}{ Kiralama Sözleşmesine Dayalı Muhtemel Nakit Girişlerinin İskonto Edilmesi } \\
\hline Aylar & 1 & 2 & 12 & 13 & 24 & 25 & 36 & \\
\hline İlk Üç Yıl Kira Ödemeleri Nominal & 0 & 38.000 & 38.000 & 39.900 & 41.895 & 45.247 & 45.247 & 1461709 \\
\hline İskonto Oranı & 1,00 & 1 & 1,09 & 1,10 & 1,20 & 1,21 & 1,32 & \\
\hline Kira Ödemelerinin Bugünkü Değeri & 0 & 38000 & 34.811 & 36.262 & 34.879 & 37.371 & 34.235 & 1263657,3 \\
\hline İkinci Üç Yıl Kira Ödemeleri & 47.510 & 47.510 & 47.510 & 49.886 & 49.886 & 52.381 & 52.381 & 1797324 \\
\hline İskonto Oran1 & 1,33 & 1,34 & 1,45 & 1,47 & 1,60 & 1,61 & 1,76 & \\
\hline Kira Ödemelerinin Bugünkü Değeri & 35.662 & 35.379 & 32.669 & 34.031 & 31.175 & 32.474 & 29.749 & 1173882,7 \\
\hline Üçncü Üç Y11 Kira Ödemeleri & 55.000 & 55.000 & 55.000 & 57.750 & & 60.636 & 60.636 & 2080632 \\
\hline İskonto Oranı & 1,77 & 1,79 & 1,94 & 1,95 & 2,1 & 2,15 & 2,35 & \\
\hline Kira Ödemelerinin Bugünkü Değeri & 30.989 & 30.743 & 28.388 & 29.571 & & 28.218 & 25.850 & 1020035,1 \\
\hline Dördüncü Üç Y1l Kira Ödemeleri & 63.668 & 63.6 & & & & 70.194 & 194 & 2408556 \\
\hline Kira Ödemelerinin Bugünkü Değeri & 26.927 & & & & & 24.519 & 462 & 886333,36 \\
\hline 5.Üç Yıl Kira Ödemeleri & 73.693 & 73.693 & 73.693 & & & 81.247 & 81.247 & 2787816 \\
\hline İskonto Oranı & 3,15 & 3,18 & 3,44 & 3,47 & 3,7 & 3,81 & 4,16 & \\
\hline Kira Ödemelerinin Bugünkü Değeri & 23.394 & 23.209 & 21.431 & 22.324 & 451 & 21.303 & 19.515 & 770061,17 \\
\hline 6.Üç Yıl Kira Ödemeleri & 85.310 & 85.310 & & & & 94.055 & 94.055 & 3227292 \\
\hline İskonto Oranı & 4,20 & 4,23 & 4,58 & 4,62 & 5,04 & 5,08 & 5,55 & \\
\hline Kira Ödemelerinin Bugünkü Değeri & 20.328 & 20. & 18. & 399 & 17.771 & 18.511 & 16.958 & 669144,93 \\
\hline 7.Üç Yıl Kira Ödemeleri & 98.758 & 98.758 & 98.758 & 103.696 & 103.696 & 108.881 & 108.881 & 3736020 \\
\hline İskonto Oranı & 5,59 & 5,64 & 6,10 & 6,15 & 6,72 & 6,77 & 7,39 & \\
\hline Kira Ödemelerinin Bugünkü Değeri & 17.664 & 17.524 & 16.182 & 16.856 & & 16.085 & 14.735 & 581449,55 \\
\hline 8.Üç Yıl Kira Ödemeleri & 114.325 & 114.325 & 114.325 & 120.041 & 120.041 & 126.043 & 126.043 & 4324908 \\
\hline İskonto Oranı & 7,45 & 7,51 & 8,13 & 8,20 & 8,95 & 9,02 & 9,84 & \\
\hline Kira Ödemelerinin Bugünkü Değeri & 15.349 & 15.227 & 14.061 & 14.647 & & 13.977 & 12.804 & 505243,38 \\
\hline 9.Üç Yı1 Kira Ödemeleri & 132.345 & 132.345 & 132.345 & 138.692 & 138.692 & 145.627 & 145.627 & 4999968 \\
\hline İskonto Oranı & 9,92 & 10,00 & 10,83 & 10,92 & 11,92 & 12,01 & 13,11 & \\
\hline Kira Ödemelerinin Bugünkü Değeri & 13.337 & 13.232 & 12.218 & 12.703 & 11.637 & 12.121 & 11.104 & 438468,8 \\
\hline \multicolumn{8}{|c|}{2017 Yılına Ait Nakit Girişlerinin Nominal Değeri } & 418.000 \\
\hline \multicolumn{8}{|c|}{2017 Sonrası Kullanma ve İșletme Sürecinde Nakit Girișlerinin Nominal Değeri (Toplam) } & 26.406 .225 \\
\hline \multirow{2}{*}{\multicolumn{8}{|c|}{$\begin{array}{c}\text { Kullanma ve İșletme Sürecinde Nakit Girișlerinin Nominal Değeri (1) } \\
2017 \text { Yilına Ait Nakit Girişlerinin Bugünkü Değeri }\end{array}$}} & 26.824 .225 \\
\hline & & & & & & & & 398.409 \\
\hline \multicolumn{8}{|c|}{2017 Sonrası Kullanma ve İşletme Sürecinde Nakit Girişlerinin Bugünkül Değeri (Toplam) } & 6.909 .867 \\
\hline \multicolumn{8}{|c|}{ Kullanma ve İşletme Sürecinde Nakit Girişlerinin Bugünkü Değeri } & 7.308 .276 \\
\hline \multirow{2}{*}{\multicolumn{8}{|c|}{$\begin{array}{c}2017 \text { Yılına İlişkin Kazanılmamıș Faaliyet Kiralaması İskonto Tutarı } \\
2017 \text { Yılı Sonrası Kullanma ve İșletme Sürecinde Kazanılmamıș Faaliyet Kiralaması İskon }\end{array}$}} & 19.591 \\
\hline & & & & & & & & 19.496 .358 \\
\hline \multicolumn{8}{|c|}{ Kazanılmamış Faaliyet Kiralaması İskonto Tutar ( Toplam) } & 19.515.949 \\
\hline
\end{tabular}




\section{YATIRIM AMAÇLI GAYRIMENKULLER HESABI}

202.01 Kadıköy.. Ada. Parsel Restorasyon ve Onarım Karşılığı Uzun Süreli Kiralama Yatırımı 202.01.001 Kira Ödemesi

202.01.002 Restorasyon ve Onarım İşleri 202.01.003 İntifa Hakkı Bedeli

Borc 202.01.04 Tefrișat ve Techizat Bedeli Alacak

01.02 .2014

..../.../.2014

.../..../2015

../.../2016

31.01 .2017

Toplam 1

03.02.2017İntifa Hakk1 Bedeli

Toplam 2

Tefrişat ve Techizat Bedeli

Toplam 3
3.450
306.500
419.400
991.400
3.450
1.724.200
2.776 .000
4.500.200
0
4.500.200

\begin{tabular}{|c|c|c|}
\hline$\ldots .1$ & & 03.02.2017 Tarihleri Arasındaki İşlemler \\
\hline 202 & \multicolumn{2}{|c|}{$\begin{array}{l}\text { YATIRIM AMAÇLI GAYRIMENKULLER HESABI } \\
\text { Kadıköy.. Ada. Parsel Restorasyon ve Onarım Karşıllığı Uzun Süreli Faaliyet Kiralamas }\end{array}$} \\
\hline 202.01 & \multicolumn{2}{|c|}{ Yatırımı } \\
\hline 202.01 .001 & \multicolumn{2}{|c|}{ Restorasyon ve Onarım İșleri } \\
\hline 202 & \\
\hline 202.01 & \multicolumn{2}{|c|}{ Yatırımı } \\
\hline 201.01 .002 & \multicolumn{2}{|c|}{ İntifa Hakkı Bedeli } \\
\hline & \multirow[t]{2}{*}{258} & YAPILMAKTA OLAN YATIRIMLAR HESABI \\
\hline & & Kadıköy.. Ada. Parsel Restorasyon ve Onarım Karşılığı Uzun Süreli \\
\hline & 258.01 & Faaliyet Kiralaması Yatırımı \\
\hline & 258.01.001 & Kira Ödemesi \\
\hline & 258.01 .002 & Restorasyon ve Onarım İşleri \\
\hline & & $\begin{array}{l}\text { YATIRIM AMAÇLI GAYRIMENKULLER DEĞER ARTIŞI } \\
\text { Kadıköy.. Ada. Parsel Restorasyon ve Onarım Karşılığı Uzun Süreli }\end{array}$ \\
\hline & 525.01 & Faaliyet Kiralaması Yatırımı \\
\hline & 525.01 .01 & İntifa Hakkı Değer Artışı \\
\hline 2017 Yili i & inde İntifa $\mathrm{H}_{\mathrm{c}}$ & ının Muhasebeleștirilmesi \\
\hline
\end{tabular}

\begin{tabular}{|c|c|c|}
\hline 2 & & 03.02 .2017 \\
\hline 136 & \multicolumn{2}{|c|}{ DİĞER ÇEŞİTLİ ALACAKLAR HESABI } \\
\hline 136.01. & \multicolumn{2}{|c|}{ Faaliyet Kiralaması Sözleşmesine Dayalı Diğer Çeşitli Alacaklar } \\
\hline 136.01 .001 & \multicolumn{2}{|c|}{ Bebek Firması } \\
\hline 136.01.001.02 & \multicolumn{2}{|c|}{ Çengelköy....Ada..Parsel. } \\
\hline 236 & \multicolumn{2}{|c|}{ DİĞER ÇEŞITTLİ ALACAKLAR HESABI } \\
\hline 236.01 . & \multicolumn{2}{|c|}{ Faaliyet Kiralamasından Diğer Çeşitli Alacaklar } \\
\hline 236.01 .001 & \multicolumn{2}{|c|}{ Bebek Firmas1 } \\
\hline 236.01.001.02 & \multicolumn{2}{|c|}{ Çengelköy...Ada..Parsel. } \\
\hline & \multicolumn{2}{|c|}{ KAZANILMAMIŞ FAALIYET KİRALAMASI İSKONTO TUTARI HESABI (- } \\
\hline 383 & \multicolumn{2}{|c|}{ ) } \\
\hline 382.01 & \multicolumn{2}{|c|}{2017 Yılına Ait İskonto Tutarı } \\
\hline 483 & \multicolumn{2}{|c|}{ KAZANILMAMIŞ FAALIYET KIIRALAMASI İSKONTO TUTARI HESABI (- } \\
\hline & \multicolumn{2}{|c|}{ ) } \\
\hline \multirow[t]{20}{*}{482.01} & \multicolumn{2}{|c|}{2018 Yılı ve Sonrası İskonto Tutarı } \\
\hline & \multirow[t]{2}{*}{137} & DİĞER ALACAK SENETLERİ REESKONTU HESABI (-) \\
\hline & & Faaliyet Kiralaması Sözleşmesine Dayalı Senetsiz Alacakların \\
\hline & 137.05 & Reeskontu \\
\hline & 137.05 .001 & 2017 Yilına Ait Reeskont Tutarı \\
\hline & & DİĞER ALACAK SENETLERİ REESKONTO HESABI (-) \\
\hline & & Faaliyet Kiralaması Sözleşmesine Dayalı Senetsiz Alacakların \\
\hline & 237.05 & Reeskontu \\
\hline & 237.05 .001 & 2017 Yilına Ait Reeskont Tutarı \\
\hline & & ALINAN DEPOZITO VE TEMINATLAR HESABI \\
\hline & 426.01 & Bebek Firması \\
\hline & 426.01 .02 & Çengelköy...Ada..Parsel. \\
\hline & & FAALIYET KIRALAMASINDAN GELECEK AYLARA AİT \\
\hline & 382 & GELİRLER HESABI \\
\hline & 382.02 & Yatırım Amaçlı Gayrimenkullerden \\
\hline & 382.02 .02 & $\begin{array}{l}\text { Çengelköy...Ada..Parsel. } \\
\text { FAALIYET KİRALAMASINDAN GELECEK YILLARA AİT }\end{array}$ \\
\hline & 482 & GELIIRLER HESABI \\
\hline & 482.02 & Yatırım Amaçlı Gayrimenkullerden \\
\hline & 482.02 .02 & Çengelköy...Ada..Parsel. \\
\hline & Kira Sözleșme & inin Muhasebeleștirilmesi \\
\hline
\end{tabular}

1.724 .20
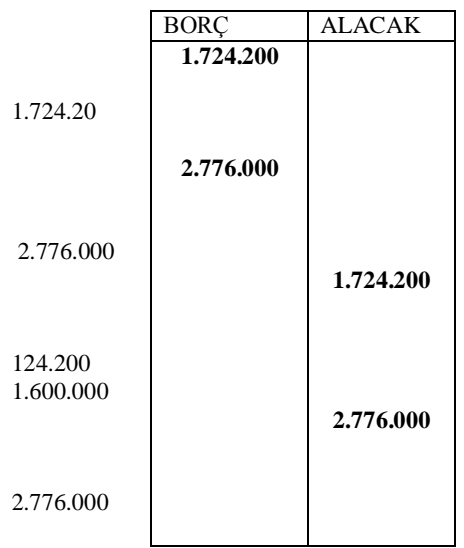

35.000

265.000

19.591

19.591

19.496 .358

19.591

19.496 .358

\begin{tabular}{|c|c|}
\hline BORÇ & ALACAK \\
\hline 418.000 & \\
\hline 26.406 .22 & \\
\hline 19.591 & \\
\hline \multirow[t]{6}{*}{19.496 .35} & \\
\hline & 19.591 \\
\hline & 19.496 .358 \\
\hline & 20.000 \\
\hline & 418.000 \\
\hline & 26.406 .225 \\
\hline
\end{tabular}


31.12.2017 tarihinde Çamlıca işletmesi yatırım amaçlı gayrimenkul için amortisman tutarını muhasebeleştirmiş̧tir. Yatırım amaçlı gayrimenkulün ekonomik ömrü kalan kira süre, yani toplam faaliyet kiralaması süresi 30 yıl, inşaat süresi 3 yıl, faydalı ekonomik ömrü 27 yıldır. Normal amortisman yöntemine göre amortisman tutarını hesaplamakta ve endirekt kayıt yöntemine göre kayıt etmektedir. Yatırım amaçlı gayrimenkulün kalıntı değeri olarak 24.200 TL olarak varsayımını dikkate almıştır. İntifa hakkı bedeline amortisman ayrılmamaktadır.

Amortismana Tabii Yatırım Amaçlı Gayrimenkulün Değeri $=1.724 .200$ TL -24.200 TL =1.700.000

Normal Amortisman Oranı $($ NAO) $=1 /$ Kiralama Süresi $=1 / 27=0,037$

Amortisman Tutart = Yatırım Amaçlı Gayrimenkulün Değeri x NAO=1.700.000 x 0,037=62.900 TL

\begin{tabular}{|c|c|c|c|c|}
\hline 3 & 03.02.2017 Tarihleri Arasındaki İșlemler & & BORÇ & ALACAK \\
\hline 740 & HIZMET ÜRETIM MALIYETI HESABI & & 62.900 & \multirow{5}{*}{62.900} \\
\hline 740.01 . & $\begin{array}{l}\text { Kadıkôy.. Ada. Parsel Restorasyon ve Onarım Karşıllığı Uzun Sürelı Faaliyet } \\
\text { Kiralaması Yatırımı }\end{array}$ & & & \\
\hline 740.01 .006 & İtfa Payları & 62.900 & & \\
\hline & $\begin{array}{ll}\mathbf{2 0 7} & \text { BİRIKMIŞ AMORTISMAN ve ITTFA PAYLARI HESABI } \\
207.02 & \text { Birikmiş İtfa Payları } \\
& \text { Kadı̈öy.. Ada. Parsel Restorasyon ve Onarım Karşıllı̆ı Uzun Süreli }\end{array}$ & & & \\
\hline $2017 \mathrm{Y}_{11} \mathrm{Ar}$ & $\begin{array}{l}\text { 207.02.001 Kiralama Yatırımı İtfa Payları } \\
\text { sman Giderinin Muhasebeleștirilmesi }\end{array}$ & 62.900 & & \\
\hline
\end{tabular}

\begin{tabular}{|c|c|}
\hline 4 & 31.02.2017 Tarihleri Arasındaki İşlemler \\
\hline 624 & $\begin{array}{l}\text { FAALIYET KIRALAMASI HIZMET ÜRETIM MALIYETI HESABI } \\
\text { Kadıköy. Ada. Parsel Restorasyon ve Onarım Kars1 } 11_{1}{ }_{1} \text { Uzun Süreli Faalivet }\end{array}$ \\
\hline $\begin{array}{l}624.01 . \\
2017 \mathrm{Y}_{1}\end{array}$ & $\begin{array}{l}\text { Kiralaması Yatırımı Hizmet Üretim Maliyeti } \\
\mathbf{7 4 1} \text { HİZMET ÜRETIM MALIYETİ YANSITMA HESABI } \\
\text { sman Giderinin Muhasebeleștirilmesi }\end{array}$ \\
\hline
\end{tabular}

\begin{tabular}{|c|r|}
\hline BORÇ & ALACAK \\
\hline $\mathbf{6 2 . 9 0 0}$ & \\
& $\mathbf{6 2 . 9 0 0}$ \\
\hline
\end{tabular}

ÖRNEK VAKA 6; İşletme (kiracı olarak) bağımsız bir üçüncü taraftan faaliyet kiralaması çerçevesinde bir bina (bina 1) kiralamıştır. Ayrıca işletme (kiraya veren olarak) bina 7’i faaliyet kiralaması çerçevesinde çeşitli bağımsız üçüncü taraflara yeniden kiralamaktadır. İşletme, bina 7'deki gayrimenkul hakkını, mal sahibinden daha yüksek bir bedelle kiralayarak kâr etmektedir.

Çözüm 6; İşletme sadece ve sadece gayrimenkul hakkının gerçeğe uygun değerini güvenilir olarak ölçebildiğinde, söz konusu binadaki kira hakkını yatırım amaçlı bir gayrimenkul kalemi olarak sınıflandırabilir ancak işletme söz konusu sınıflandırma hususunda zorunlu tutulmaz. Binadaki kiralamadan doğan hak, yatırım amaçlı gayrimenkul tanımını karşıladığı için (yani, kira kazancı için elde tutulmaktadır) bu sınıflandırmaya izin verilir. Söz konusu gayrimenkul hakkının yatırım amaçlı bir gayrimenkul olarak muhasebeleştirilmesinin seçilmesi halinde hak, yani bir varlığın (yatırım amaçlı gayrimenkul) ve bir borcun (kira ödemeleri yapma yükümlülüğü) olması durumunda muhasebeleştirilir Gayrimenkul hakkının gerçeğe uygun değerinin güvenilir şekilde ölçülemediği durumlarda, binadaki kiralamadan doğan haklar yatırım amaçlı bir gayrimenkul kalemi olarak muhasebeleştirilemez. Bu faaliyet kiralamasına olarak muhasebeleştirilir.

ÖRNEK VAKA 7; Koşullar Örnek 6'daki koşullarla aynıdır. Ancak bu örnekte işletme, bina 7'deki hakkını yatırım amaçlı gayrimenkul olarak muhasebeleştirmeyi seçmiştir. Sonraki bir raporlama döneminde işletme (kiracı olarak) faaliyet kiralaması çerçevesinde bağımsız üçüncü bir taraftan başka bir bina (bina 8) kiralamış ve bina 8'yi faaliyet kiralaması çerçevesinde (kiraya veren olarak) bağımsız bir üçüncü tarafa yeniden kiralamıştır. İşletme 
bina 7 ve bina 8 'deki haklarının gerçeğe uygun değerini güvenilir olarak ölçebilmektedir. İşletme bina 8'e İlişkin kiralamayı gerçeğe uygun değeri üzerinden gösterilen bir yatırım amaçlı gayrimenkul olarak değil, bir faaliyet kiralaması olarak muhasebeleştirmek istemektedir (Dabbağoğlu, 2017:109-110).

Çözüm 7; İşletme bina 8'e ait yeni kiralamayı faaliyet kiralaması olarak muhasebeleştirebilir. Her bir gayrimenkul için ayrı ayrı değerlendirilir.

ÖRNEK VAKA 8; Bir işletme (kiracı olarak), bağımsız bir üçüncü taraftan ( gayrimenkulün sahibi) faaliyet kiralaması kapsamında bir bina kiralamıştır. Ayrıca, işletme (kiraya veren olarak), gayrimenkulde oturan farklı bir bağımsız üçüncü tarafa binayı, faaliyet kiralaması kapsamında kiraya vermiştir. İşletme kira hissesi üzerinden; kiracısını, kiraya veren tarafından ücretlendirildiğinden daha fazla tutarda ücretlendirerek kâr elde etmektedir. İşletme, bina üzerindeki kira payını/hissesini yatırım amaçlı gayrimenkul olarak muhasebeleştirmeyi seçmiştir. İşletme, gayrimenkulün faydasının (gayrimenkulden elde ettiği kazancının) gerçeğe uygun değerini güvenilir bir şekilde ölçebilmektedir (Dabbağoğlu, 2017:110-111).

Çözüm 8; Sözleşme bir faaliyet kiralaması işlemidir. Kiraya verenin, kiracıya (işletmeye), bir ödeme ya da ödeme planı karşılığında varlığın kullanım hakkını kararlaştırılan süre için devrettiği bir sözleşmedir. Ancak işletme, bina üzerindeki hissesini yatırım amaçlı gayrimenkul olarak muhasebeleştirmeyi seçtiği için, binadaki hissesini varlık (yatırım amaçlı gayrimenkul) ve borç (kira ödemeleri için yükümlülük) olarak muhasebeleştirmelidir. Not: İşletme gayrimenkulde sahip olduğu hissenin gerçeğe uygun değerini güvenilir bir şekilde ölçemiyorsa, kiralama hissesini yatırım amaçlı gayrimenkul olarak muhasebeleştirmeyi seçmesi yasaklanmıştır. Bu koşullar çerçevesinde, faaliyet kiralamasına ilişkin hükümler uygulanır.

ÖRNEK VAKA 9; Örnek Vaka 8'de yer alan işletmenin söz konusu gayrimenkul hakkının gerçeğe uygun değerini güvenilir bir şekilde ölçebildiğini varsayalım. Sonraki bir raporlama döneminde işletme başka bir bina (bina 10) satın almış ve (kiraya veren olarak) bina 10'ü faaliyet kiralaması çerçevesinde bağımsız bir üçüncü tarafa kiralamıştır. İşletme bina 10'un gerçeğe uygun değerini aşırı maliyet ve çabaya katlanmaksızın sürekli olarak belirleyebilmekte olup, söz konusu binayı gerçeğe uygun değeri üzerinden muhasebeleştirmeyi seçmektedir (Dabbağoğlu, 2017:109-110).

Çözüm 9; İşletme bina 7 ve 10'teki haklarını gerçeğe uygun değer üzerinden ölçülen yatırım amaçlı gayrimenkul olarak muhasebeleştirir. Bina 8'deki hakkı faaliyet kiralaması olarak muhasebeleştirilir. Karma kullanımlı gayrimenkul, yatırım amaçlı gayrimenkul ile maddi duran varlık arasında bölünür. Ancak, yatırım amaçlı gayrimenkul unsurunun gerçeğe uygun değeri aşırı maliyet veya çabaya katlanmaksızın ölçülemiyorsa, gayrimenkulün tamamı maddi duran varlık olarak muhasebeleştirilir.

ÖRNEK VAKA 10; İşletme kira ödemeleri karşıllı̆ında faaliyet kiralaması çerçevesinde bağımsız üçüncü taraflara kiraladığı bir binaya sahiptir. Ancak işletmenin bina yönetici ve bakım personeli, binanın yüz ölçümünün yüzde 1 'inden daha az bir kısmına denk gelen ofisleri kullanmaktadır. 
Çözüm 10; Bina, işletme (kiraya veren) tarafından yatırım amaçlı bir gayrimenkul olarak sınıflandırılır. Söz konusu bina kira kazancı için elde tutulan bir gayrimenkuldür. Binanın sahibi tarafından kullanılan bölümü (sahibi tarafından kullanım) önemsiz olduğundan ihmal edilebilir.

ÖRNEK VAKA 11; İşletme kira ödemeleri karşılı̆̆ında faaliyet kiralaması çerçevesinde bağımsız üçüncü taraflara kiraladığı bir binaya sahiptir. İşletmenin bina yönetici ve bakım personeli, binanın yüz ölçümünün yüzde 25'ine denk gelen ofisleri kullanmaktadır.

Çözüm 11; İşletme (sahip) binanın önemli bir bölümünü (yüz ölçümünün yüzde 25’i) kullanmaktadır. Kira kazancı veya sermaye değer artış kazancı ya da her ikisi için elde tutulan ve mal ve hizmet üretim veya tedarikinde kullanmak için elde tutulan bölümlerin ayrı ayrı satılabilmesi veya finansal kiralama çerçevesinde ayrı olarak kiralanması halinde işletme, söz konusu bölümleri ayrı ayrı muhasebeleştirebilir. Yatırım amaçlı gayrimenkul bölümü, maddi duran varlık bölümünden ayrılabilir. Ancak, yatırım amaçlı gayrimenkul bileşeninin gerçeğe uygun değerinin aşırı maliyet ve çabaya katlanmaksızın güvenilir olarak sürekli şekilde ölçülemediği durumlarda, gayrimenkulün tamamı maliyet, amortisman ve değer düşüklüğü kayıplarını da dikkate alınarak maddi duran varlık olarak muhasebeleştirilir.

ÖRNEK VAKA 12; İşletme iki katlı bir binaya sahiptir. 1 inci kat kira ödemeleri karşılığında faaliyet kiralaması çerçevesinde bağımsız üçüncü taraflara kiralanmıştır. 2 nci kat işletmenin yönetici ve bakım personeli tarafindan kullanılmaktadır. İşletme her katın gerçeğe uygun değerini aşırı maliyet ve çabaya katlanmaksızın güvenilir olarak ölçebilmektedir.

Çözüm 12; Binanın 1 inci katı işletme (kiraya veren) tarafından yatırım amaçlı bir gayrimenkul kalemi olarak sınıflandırılır. Söz konusu kat, kira kazancı için elde tutulan bir gayrimenkuldür. Her raporlama tarihinde gerçeğe uygun değeri üzerinden muhasebeleştirilir. Binanın 2 nci katı maddi duran varlık olarak sinıflandırılır. Söz konusu kat, mal veya hizmet üretim ya da tedarikinde kullanılmak için veya idari amaçlarla elde tutulan bir gayrimenkuldür Maliyetinden birikmiş amortisman ve değer düşüklükleri indirildikten sonraki tutar üzerinden muhasebeleştirilir. Not: Gerçeğe uygun değerin aşırı maliyet ve çabaya katlanmaksızın güvenilir olarak sürekli şekilde ölçülemediği durumlarda, 1 inci ve 2 nci katlar tamamı maddi duran varlık olarak muhasebeleştirilir. Yatırım amaçlı gayrimenkul, ilk muhasebeleştirmede maliyet bedeli ile ölçülür. Satın alınan yatırım amaçlı gayrimenkulün maliyeti; satın alma fiyatı ile bu işlemle doğrudan ilişkilendirilebilen avukatlık ve aracılık hizmetlerine ilişkin ödenen ücretler, gayrimenkul alım vergisi ve diğer işlem maliyetleri gibi harcamalardan oluşur. Ödeme, normal kredi şartlarının ötesine ertelenmişse maliyet, gelecekteki tüm ödemelerin bugünkü değeridir.

\section{SONUÇ}

Yatırım amaçlı gayrimenkulün ilk ediniminde maliyet bedeli üzerinden muhasebeleştirilmesini gerektirir. Yatırım amaçlı gayrimenkulün gerçeğe uygun değerinin elde edilecek faydanın üzerinde bir maliyete katlanmaksızın güvenilir olarak sürekli şekilde belirlenebildiği durumlarda, gerçeğe uygun değer yöntemi kullanılmalıdır.

Yatırım amaçlı gayrimenkullerin, değerleme fonksiyonları, işletmenin sürekliliğini sağlayan en önemli unsurlardan biridir. Değerleme fonksiyonlarından beklenen faydanın 
sağlanabilmesi, seçilen değerleme ölçülerinin doğruluğu kadar, dönemler arası tutarlılığına da bağlıdır.

Bir işletme istediği takdirde bir varlık üzerindeki haklarını gerçeğe uygun değer üzerinden yatırım amaçlı gayrimenkul olarak muhasebeleştirir. Hesap Planında boş olan 200 grubu içerisinde 202 Yatırım Amaçlı Gayrimenkul adıyla bir hesap açılabilir ve burada takip edilebilir. İsterse de faaliyet kiralaması olarak muhasebeleştirilir. Karma kullanımlı gayrimenkul, yatırım amaçlı gayrimenkul ile maddi veya maddi olmayan duran varlık arasında bölünür. Yatırım amaçlı gayrimenkul unsurunun gerçeğe uygun değeri aşırı maliyet veya çabaya katlanmaksızın ölçülemiyorsa, gayrimenkulün tamamı maddi veya maddi olmayan duran varlık olarak muhasebeleştirilir.

Yatırım amaçlı bir gayrimenkulün amortismanın hesaplanması sürecinde kalıntı değerin belirlenmesi gereklidir. Yatırım amaçlı gayrimenkulün bünyesinde arsa payı için amortisman ayrılmayacaktır. Amortisman tutarı hesap planında boş olan 200 grubu içerisinde aktifi düzenleyici bir hesap olarak 207 Birikmiş Amortiman ve İtfa Payı Hesabında (-) takip edilir. Yatırım amaçlı gayrimenkul işletmenin aktifinde kayıtlı bir varlığın kullanım amacının değişmesinden kaynaklanıyorsa 207 Birikmiş Amortisman ve İtfa Payı Hesabının () alt tali hesabında 207.01. Birikmiş Amortisman Hesabında, yatırım amaçlı gayrimenkul bir faaliyet kiralaması sözleşmesinden, restorasyon ve onarım karşılığı uzun vadeli faaliyet kiralaması sözleşmesinden ve maddi olmayan bir varlığın kullanım amacının değişmesinden kaynaklanıyorsa 207 Birikmiş Amortisman ve İtfa Payı Hesabının (-) alt tali hesabında 207.02. Birikmiş İtfa Payları Hesabında takip edilmelidir.

Yatırım amaçlı gayrimenkulün değerinin düşmesi, kayıp olması veya terk edilmesi nedeniyle üçüncü şahıslardan alınacak tazminat tahsil edilebilir olduğu zaman gelir tablosu ile ilişkilendirilir.

Yatırım amaçlı gayrimenkulün kullanım dışı kalması veya elden çıkarılması durumunda meydana gelen kazanç veya kayıplar; varlığın elden çıkarılmasından kaynaklanan net hasılat ile gayrimenkulün defter değeri arasındaki farktır ve kullanıma son verilme veya elden çıkarılma döneminde gelir tablosunda muhasebeleştirilir.

Yatırım amaçlı bir gayrimenkulün elden çıkarılması karşılığında alınacak tutarlar başlangıçta gerçeğe uygun değer esasına göre muhasebeleştirilir. Özellikle yatırım amaçlı gayrimenkul için yapılacak ödemelerin ertelenmiş olması durumunda, alınacak söz konusu tutarlar, ödemelerin kayıt tarihindeki iskonto edilmiş değerleri üzerinden muhasebeleştirilir.

Kiraya verenin, kiracıya (işletmeye), bir ödeme ya da ödeme planı karşılığında varlığın kullanım hakkını kararlaştırılan süre için devrettiği bir sözleşmeye bağlı kiralama işlemine faaliyet kiralaması denir ve TFRS 16 esaslarına göre muhasebeleştirilir. Bazen işletmeler, yapmış oldukları doğrudan veya restorasyon veya onarım karşılığı uzun süreli faaliyet kiralaması sonucunda sahip oldukları hakkın gerçeğe uygun değerini güvenilir olarak ölçebildiğinde, söz konusu hakkını yatırım amaçlı bir gayrimenkul kalemi olarak sınıflandırabilir ancak işletme söz konusu sınıflandırma hususunda zorunlu tutulmaz. Faaliyet kiralamasından doğan hak, yatırım amaçlı gayrimenkul tanımını karşıladığı için (yani, kira kazanc1 için elde tutulmaktadır) bu sınıflandırmaya izin verilir. Söz konusu gayrimenkul hakkının yatırım amaçlı bir gayrimenkul olarak muhasebeleştirilmesinin seçilmesi halinde 
hak, yani bir varlığın (yatırım amaçlı gayrimenkul) ve bir borcun (kira ödemeleri yapma yükümlülüğü) olması durumunda muhasebeleştirilir. Gayrimenkul hakkının gerçeğe uygun değerinin güvenilir şekilde ölçülemediği durumlarda, binadaki kiralamadan doğan haklar yatırım amaçlı bir gayrimenkul kalemi olarak muhasebeleştirilemez. Sadece faaliyet kiralaması olarak muhasebeleştirilir.

Bir işletme faaliyet kiralaması yoluyla edindiği bir varlığı üçüncü bir kişiye faaliyet kiralaması yoluyla kiraya verebilir. Ya da restorasyon ve onarım karşılığ faaliyet kiralama sözleşmesinden kaynaklanan hakkını üçüncü bir kişiye faaliyet kiralaması yoluyla edindiği hakkı devir edilebilir. Yapılan faaliyet kiralaması sözleşmesindeki yükümlülüklerin bugünkü değeri veya restorasyon ve onarım inşa maliyetinin bugünkü değeri ile 3 . Kişiden elde edilebilecek kira gelirlerinden nakit girişlerinin bugünkü değeri veya restorasyon ve onarım karşılığ1 edinilen varlığın işletilmesinden elde edilecek muhtemel nakit girişlerinin net bugünkü değeri arasındaki fark intifa hakkı olarak yatırım amaçlı gayrimenkulün tali hesaplarında ve 525 Yatırım Amaçlı Gayrimenkuller Değer Artış Hesabında muhasebeleştirilir. İntifa hakkı hesaplanırken; varlığın gerçeğe uygun değeri ile net bugünkü değerinden düşük olanı ihtiyatlılık kavramı gereği dikkate alınır. İntifa hakkı için itfa payı ayrılmayacaktır. Her yıl hakkın devir bedeline ilişkin gerçeğe uygun değer araştırması yapılacak ve artış veya azalışlar ilgili intifa hakkı bedeli tali hesabı, 525 Yatırım Amaçlı Gayrimenkuller Değer Artış Hesapları kullanılarak raporlama tarihindeki değeri doğru ve gerçek olarak ifade edilecektir. 525 Yatırım Amaçlı Gayrimenkuller Değer Artışı Hesabındaki değişim Kapsamlı Gelir Tablosun da raporlanacaktır.

İntifa hakkının veya değer artışının söz konusu olmadığı yatırım amaçlı gayrimenkulün değerinde bir kaybın oluşması durumunda, ilgili kayıp 200 grubu içerisinde 203 Yatırım Amaçlı Gayrimenkuller Değer Kaybı (-) Gelir tablosunda da 654 Kayıp ve Karşılık Gideri Hesabında takip edilebilir. Dönem sonunda ilgili tutar ertelenmiş vergi doğuracağından gerekli muhasebe kaydı yapılmalıdır.

İşletmeler, bir arsayı belirli bir kar marjı ile bütününü veya küçük parsellere ayırarak satmak amacıyla, ana faaliyeti kapsamı dışında olmasına rağmen, elde edinmişse, Yatırım Amaçlı Gayrimenkul Hesabı yerine Satış Amaçlı Gayrimenkuller hesabında muhasebeleştirmelidir. Satış amaçlı gayrimenkuller Finansal Durum Tablosunda (Bilanço) dönen varlıklar birinci toplamından sonra yer almalı ve dönen varlıklar ikinci toplam kapsamında olmalıdır. Muhasebe uygulamaları genel tebliği doğrultusunda hazırlanan hesap planında dönen varlıklar grubu içerisinde satış amaçlı gayrimenkuller adıyla bir hesap yoktur. $\mathrm{Bu}$ nedenle gerektiğinde boş olan 200 grubu içerisinde 201 Satış Amaçlı Gayrimenkul adıyla bir hesap açılabilir ve burada takip edilebilir. TMS 2 stoklar standardı kapsamında değerlendirilmelidir. $\mathrm{Bu}$ sebeple raporlama anında hesapta bulunan tutarı duran varlıklar toplamından çıkartılmalı ve dönen varlıklar birinci toplamından sonra yer almak üzere finansal durum tablosu, hazırlanmalıdır. Çünkü ilgili tutarın dönen varlıklar da yer alması işletmenin finansal rasyoları açısından da önemlidir.

İşletmeler bir arsayı, belirli bir kar marjı ile bütününü veya küçük parsellere ayırarak satmak amacıyla, ana faaliyet kapsamında elde etti ise, ilgili arsayı Yatırım Amaçlı Gayrimenkul Hesabı yerine 152 Ticari Mallar hesabında takip etmelidir. Yatırım amaçlı gayrimenkul amacı ile satın alınan arsa sebebiyle katlanılan finansman giderleri arsa maliyetine dahil edilmeyecek ve gelir tablosu ile ilişkilendirilecektir. 
Bir işletmesi dönemsellik kavramı gereği dönem ayrıştırıcı hesapları kullanırken alacak ve borç ile gelirlerinin kayıtlarını, yevmiye kayıt tarihi itibariyle gerçeğe uygun değerlerini dikkate alarak yapıyorsa; 236 ve 136 Diğer Çeşitli Alacaklar Hesabı için aktif düzenleyici düzenleyici hesap olan 237, 137 Diğer Alacak Senetleri Reeskontu (-) Hesabının alt hesaplarında Faaliyet Kiralaması Sözleşmesine Dayalı Çeşitli Alacaklar Reeskontu Tali Hesabında; dönem ayrıştırıcı hesap olan 482 Faaliyet Kiralamasından Gelecek Yıllara Ait Gelirler ile 382 Faaliyet Kiralamasından Gelecek Aylara ait Gelirler için boş olan ve pasif düzenleyici hesap olarak 383 Kazanılmamış Faaliyet Kiralaması Gelirleri İskonto Tutarı ve 483 nolu Kazanılmamış Faaliyet Kiralaması Gelirleri İskonto Tutarı Hesapları kullanılabilir. 436 ve 336 Diğer Çeşitli Borçlar Hesapları için pasif düzenleyici hesap olarak 437 ve 337 Diğer Borç Senetleri Reeskontu(-) Hesabının alt hesaplarında Faaliyet Kiralaması Sözleşmesine Dayalı Çeşitli Borçlar Reeskontu Tali Hesabında, 182, 282 Faaliyet Kiralamasından Gelecek Aylara Ait Giderler Hesapları için aktif düzenleyici hesap olarak ve 183 Ertelenmiş Faaliyet Kiralaması Giderleri İskonto Tutarı (-) ve 283 Ertelenmiş Faaliyet Kiralaması Giderleri İskonto Tutarı (-) hesapları kullanılabilir.

Eğer faaliyet kiralaması yoluyla bir gelir elde edilmiş ise ilgili gelirler 604 Faaliyet Kiralamasından Gelir ve Karlar hesabında ve ilgili gelir için katlanılan maliyetlerde bir hizmet maliyeti olarak 624 Faaliyet Kiralaması Hizmet Üretim Maliyeti hesabında takip edilebilir.

Sözleşmeye dayanan hak ve yükümlüklerin nazım hesaplarda takip edilmesi de mali tabloların güvenilirliği, işletmenin sürekliliği hakkında bilgi sahibi olmak ve tam açıklama kuralına uymak için önemlidir.

\section{KAYNAKLAR}

Deloitte Academy,Kapsamlı UFRS Eğitimi, “UMS 40 Yatırım Amaçlı Gayrimenkuller”, 1-8.

Burgu Nusret Vural, "Sat ve Geri Kirala (Sale and Leaseback) Yönteminin Mevzuat Kapsamında Değerlendirilmesi ve Muhasebeleştirilmesi” İstanbul Ticaret Üniversitesi, Dış Ticaret Enstitüsü, Working Paper Series, Tartışma Metinleri, WPS NO: 74 / 2017 $-02,1-23$.

Dabbağoğlu Kadir, Finansal Muhasebe Dönem Sonu Değerleme İşlemleri, Eğitim Yayınevi, Haziran 2017, s.103-119.

Gökgöz Ahmet, "Finansal Kiralama İşlemlerinin Muhasebeleştirilmesi”, Dumlupınar Üniversitesi Sosyal Bilimler Dergisi, Say1 35, Ocak 2013, 107-121.

Gökgöz Ahmet, "Yatırım Amaçlı Gayrimenkullerin Muhasebeleştirilmesi" İktisadi ve İdari Bilimler Dergisi, Cilt: 29 Say1: 3, 2015, 459-477.

Gücenme Gençoğlu Ümit, "Maddi Duran Varlıklar ve Yatırım Amaçlı Gayrimenkuller", Sakarya Üniversitesi Sürekli Eğitim Uygulama ve Araştırma Merkezi, Eğitim Notları, $1-49$. 
Güngör Ayşe Nur, Yatırım Amaçlı Gayrimenkullerin Muhasebeleştirilmesi, Yüksek Lisans Tezi, Marmara Üniversitesi, Sosyal Bilimler Enstitüsü, Muhasebe Finansman Bilim Dal1, İstanbul 2011.

Küçük Sema, "Yatırım Amaçlı Gayrimenkuller Vergi Uygulamas1- Muhasebe Standartları Karşılaştırması" Vergi Dünyası Dergisi, Sayı:374. Ekim 2012.

Muhasebe Sistemi Uygulama Genel Tebliği, 1seri nolu, 26.12.1992 tarihli 21447 sayılı Resmi Gazete

Netek Okan, "TMS 40 Yatırım Amaçlı Gayrimenkuller Standardı" Yaklaşım Dergisi, Say1:236. Ağustos 2012.

Örten Remzi- Kaval Hasan- Karapınar Aydın, Türkiye Muhasebe Finansal Raporlama Standartları Uygulama ve Yorumları, Ankara: Gazi Kitabevi, 6.Bask1. Nisan 2012.

Şentürk Fatih, "Türk Vergi Mevzuatı Kapsamında Faaliyet Kiralaması Yapan İşletmelerde Muhasebe Uygulamaları” Journal of Business Research Türk, 8/1 (2016) 619-639.

TOKAY Hüseyin- Deran Ali- Aktaş Rafet. "Uluslararası Muhasebe ve Finansal Raporlama Standartlarında Gerçeğe Uygun Değer Yaklaşımı ve Muhasebe Uygulamalarına Etkisi” Muhasebe Bilim Dünyası Dergisi, Cilt:7, Sayı:4, Aralık 2005.

Tokay Semih Hüseyin- Deran Ali, "Türkiye Muhasebe ve Finansal Raporlama Standartları'nda Değerleme Ölçüleri” Mali Çözüm Dergisi, 2008, Sayı:90.

Ufuk Mehmet Tahir, Vergi Usul Kanunu ve Tekdüzen Hesap Planına Göre Amortisman Uygulamaları, s. TÜRMOB Yayınları, 2008.

Üner Fatih, Türkiye Muhasebe Standardı 40 Çerçevesinde Yatırım Amaçlı Gayrimenkulün Muhasebeleştirilmesi, Yüksek lisans Tezi, Balıkesir Üniversitesi, Sosyal Bilimler Enstitüsü, Muhasebe Finansman Bilim Dalı, 2015.

Yıldız Ferah- Kara Ekrem- Yanık Ahmet, "KOBİ-TFRS'ye Göre Kiralama İşlemlerinin Muhasebesi”, AİBÜ Sosyal Bilimler Enstitüsü Dergisi, Cilt:14, Y1l:14, Sayı:1, 14:461 478

Yıldız Salih, Yatırım Amaçlı Gayrimenkuller (TMS 40) ve Bir Uygulama, Yüksek Lisans Tezi, İstanbul Ticaret Üniversitesi, Sosyal Bilimler Enstitüsü, İşletme Anabilim Dalı, Muhasebe ve Denetim Bilim Dal, İstanbul 2010.

Türkiye Finansal Raporlama Standardı 16, Kiralamalar

Türkiye Muhasebe Standardı 40, Yatırım Amaçlı Gayrimenkuller 